\title{
ВОПРОСЫ ТЕКСТОЛОГИИ
}

DOI 10.22455/2541-8297-2018-10-393-427

УДК 812.161 .1

\section{Новые датировки пятидесяти писем Н.В. Гоголя}

\author{
(C) 2018, И.А. Виноградов
}

\begin{abstract}
Аннотация: Статья посвящена воссозданию объективной картины гоголевской переписки и биографии. Исправлены датировки пятидесяти писем Гоголя к разным адресатам. Представлены исключительно существенные случаи ошибочных датировок, допускающие неверное соотнесение послания от месяцев до нескольких лет. В статье не рассматриваются те случаи, когда разница в датировках заключается в одном-двух днях, когда Гоголь при составлении письма датирует его одним днем, а отправляет на следующий день или через день. Новое, соответствующее реальности хронологическое приурочение получили письма всех периодов биографии и творчества Гоголя: семь писем 1840 г., по шесть писем 1849 и 1850 гг., пять писем 1839 г., четыре - 1851, три - 1837, по два письма 1838, 1841, 1844, 1845, 1848 и 1852 гг., по одному письму 1822, 1836, 1840-1841, 1842, 1843 и (одно) 1848 или 1851 гг. В аргументации использованы многочисленные историко-архивные материалы, биографические сведения, мемуарные и эпистолярные источники и пр.

Ключевые слова: Гоголь, биография, творчество, эпистолярное наследие, датировки, адресаты
\end{abstract}

Информация об авторе: Игорь Алексеевич Виноградов, доктор филологических наук, главный научный сотрудник, ИМЛИ РАН, Москва.

E-mail: info@imli.ru

Цитирование: Виноградов И.А. Новые датировки пятидесяти писем Н.В. Гоголя // Литературный факт. 2018. № 10. С. 393-427. 
В академическом издании сочинений Н.В. Гоголя 1937-1952 гг. десятки писем датированы неверно. В настоящей статье не рассматриваются те случаи, когда разница в датировках заключается в одном-двух днях. Порой Гоголь при составлении письма датирует его одним днем, а отправляет на следующий день или через день. Таких случаев довольно много, но предметом исключительного внимания в данной работе являются лишь очень существенные ошибки в датировках. Таких немаловажных промахов, искажающих общую картину гоголевской переписки и биографии, оказалось ровно пятьдесят. Это касается как ранних писем Гоголя, так и позднейших. Наиболее значительное число ошибок встречается в т. 11 академического издания, включающем письма 1836-1841 гг. В комментировании этого тома было занято одиннадцать ученых, так что вышло вполне по пословице: «У семи нянек дитя без глазу». Исправления и уточнения датировок располагаются в хронологическом порядке.

\section{1}

Годом позже, сравнительно с прежним хронологическим приурочением, следует датировать письмо юного Гоголя к родителям из Нежина, которое В.И. Шенрок ${ }^{1}$ и вслед за ним В.В. Каллаш ${ }^{2}$ и С.Н. Дурылин ${ }^{3}$ относили к декабрю 1821 г. Новая дата - декабрь 1822 г. - предложена на основании уточненной датировки записей классных надзирателей Гоголя и анализа содержания его переписки 1821-1823 гг.

В письме Гоголь сообщает родителям: «Третьего дни я был у Ивана Семеновича, и он говорил, ежели я буду хорошо весть себе, то он отпустит меня домой на праздник». Речь идет о директоре Нежинской гимназии И.С. Орлае. Письмо может относиться только к 1822 г., так как в декабре 1821 г, согласно надзирательским замечаниям (точная датировка которых устанавливается впервые), Гоголь характеризовался неудовлетворительным поведением, что не соответствует его желанию хорошо себя вести (чтобы быть отпущенным домой), которое он, согласно тексту письма, высказал Орлаю. В 1821 г. Гоголь был наказан за плохое поведение четырежды: в первой половине декабря, 17, 19 и 20 C. 12 .

$1<$ Гоголь Н.В.> Письма Н.В. Гоголя. Ред. В.И. Шенрока. СПб., <1901>. Т. 1. 193.

Каллаш В. Письмо в редакцию // Русская Мысль. 1902. № 10. <Отд. 2>. С. $192-$

3 Гоголь Н.В. Полн. собр. соч.: В 14 т. <Л.>, 1940. Т. 10 / Тексты и коммент. подгот. И.Я. Айзеншток, Г.А. Бялый, Г.С. Виноградов, Ц.С. Вольпе, В.В. Гиппиус, Б.П. Городецкий, А.И. Грушкин, А.Г. Дементьев, С.Н. Дурылин, А.И. Комаров, Л.В. Крестова, А.Н. Михайлова, Л.Б. Модзалевский, Н.И. Мордовченко, А.А. Назаревский, Л.А. Плоткин, И.Г. Ямпольский. С. 391. 
декабря. А 23 декабря гимназисты уже были отпущены на каникулы, тогда как Гоголь, вероятно, именно вследствие неудовлетворительного поведения, поездки домой был лишен и провел Рождественские каникулы в стенах нежинского пансиона ${ }^{4}$. Учтя отрицательный опыт 1821 г., Гоголь на следующий год, в декабре 1822 г., постарался вести себя лучше (хотя и на этот раз домой он все-таки не попал; родители за ним тогда не приехали). Исключенное из числа писем 1821 г., письмо не может быть приурочено и к 1823 г., так как к декабрю этого года относятся сразу два гоголевских письма с аналогичной просьбой к родителям взять его домой на каникулы: от ноября - начала декабря и от 11 декабря 1823 г. Маловероятно, чтобы комментируемое письмо было еще одним - третьим - посланием 1823 г. с такой же просьбой.

Очевидным недосмотром исследователей объясняется датировка общего письма Гоголя к матери и сестре Марии с упоминанием о географических картах, прислать которые обещала ему сестра: «...Она писала мне о картах, которые где-то видела. Если там есть карты Галиции, Буковины, Кроации, Венгрии, Богемии, Трансильвании, Померании и вообще западных славянских земель и Австрии, то пусть приобретет». Речь, несомненно, идет о тех картах, за намерение прислать которые Гоголь благодарил сестру в письме от 10 ноября 1835 г.: «Благодарю тебя за усердие, с которым ты стараешься наделить меня старинными картами...» Между тем, вслед за П.А. Кулишом ${ }^{5}$, все исследователи ${ }^{6}$ допускали ошибку, относя комментируемое письмо к апрелю 1834 г., т.е. считая его написанным двумя годами ранее. С.Н. Дурылиным были даже приведены малозначительные аргументы в пользу такой датировки. Основанием для отнесения письма к 1834 г. служило лишь то, что «в письме говорится о “прекрасной погоде, совершенном лете" на пасхальной неделе (пасха была 22 апреля); это было именно в 1834 г. (следует ссылка на письмо Гоголя к матери от 20 апреля 1834 г. - И.В.)»7. Между тем такая же «летняя» погода стояла в Петербурге и на Пасху 1836 г. - 29 марта. В письме к матери от 12 мая 1836 г. Гоголь сообщал: «В средине апреля

\footnotetext{
${ }^{4}$ См.: Виноградов И.А. Летопись жизни и творчества Н.В. Гоголя (1809-1852). С родословной летописью (1405-1808). Научное издание: В 7 т. Т. 1: 1405-1808; 1809-1828. М., 2017. С. 342-345.

$5<$ Гоголь Н.В.> Соч. и письма Н.В. Гоголя. $<$ В 6 т.> Изд. П.А. Кулиша. СПб., 1857. T. 5. C. 209-210.

6 В.Б. <Бирюкович В.В.> Письма Н.В. Гоголя // Вестник Европы. 1896. № 6. С. 736-737; Письма Н.В. Гоголя. Ред. В.И. Шенрока. Т. 1. С. 294-295.

${ }^{7}$ Гоголь Н.В. Полн. собр. соч.: В 14 т. Т. 10. С. 478.
} 
было так тепло, как летом...» Кроме того, датировать письмо апрелем 1834 г. не позволяет то обстоятельство, что перерыва в письмах матери к Гоголю в тот период не было ${ }^{8}$, тогда как в комментируемом письме Гоголь замечает: «Вы что-то давно ${ }^{9}$ уж не пишете ко мне». Последнему замечанию вполне соответствуют слова Гоголя в еще более позднем письме к матери 1836 г. - от 12 мая: «Я получил письмо ваше после долгого молчания...»

Что особенно важно в датируемом по-новому письме Гоголя (от конца марта - начала апреля 1836 г.) — в нем упоминаются предпасхальные хлопоты: «...Хотел-было к празднику прислать вам и сестре красных яичек, но так был захлопотан, что никак не успел». Скорее всего, это были хлопоты по постановке комедии «Ревизор» в Александринском театре, премьера которой состоялась 19 апреля.

\section{3}

Уточнены датировка и литературный замысел письма Гоголя к П.А. Плетневу, помеченного самим писателем: «Рим. 2 ноября 1837 г.», — но на самом деле отправленного из Рима почти месяц спустя, 30 ноября (н. ст.) 1837 г. Письмо предназначалось для публикации в журнале «Современник» и даже имеет дату цензурного разрешения, подписанного цензором А.В. Никитенко, - 28 марта 1838 г. Это обстоятельство не позволяет печатать указанное письмо (как это делалось ранее) в ряду других гоголевских посланий, а заставляет отнести его в ряд литературных произведений Гоголя эпистолярного жанра ${ }^{10}$.

\section{4}

Такая же датировка - новая сравнительно с традиционно принятой - предложена для письма Гоголя к В.А. Жуковскому, помеченного: «Октября 30. Рим. 1837». В действительности это письмо было так же, как и письмо к Плетневу, отправлено адресату из Рима 30 ноября (н. ст.) 1837 г.

${ }^{8}$ См.: Виноградов И.А. Летопись жизни и творчества Н.В. Гоголя (1809-1852). T. 2. C. 303-305.

9 С февраля 1836 г. (см.: Виноградов И.А. Летопись жизни и творчества Н.В. Гоголя (1809-1852). Т. 2. С. 486).

10 См.: Гоголь Н.В. <Письмо из Рима к редактору журнала «Современник» П.А. Плетневу> // Гоголь Н.В. Полн. собр. соч. и писем: В 17 т. Сост., подгот. текстов и коммент. И.А. Виноградова, В.А. Воропаева. М.; Киев, 2009. Т. 7. С. 525-526, 760-763; Виноградов И.А. Неузнанное произведение Гоголя // Духовная традиция в русской литературе. Сб. научных статей / Науч. ред., сост. Г.В. Мосалевой. Ижевск, 2013. C. 236-248. 
Гоголь вернулся в Рим лишь в конце ноября (н. ст.) 1837 г. ${ }^{11}$ Он датирует свое письмо октябрем (а не ноябрем), возможно, по ошибке, но скорее всего - во избежание недоразумений, которые могли бы возникнуть у Жуковского и его окружения при последующей публикации гоголевского <Письма из Рима к редактору журнала «Современник» П.А. Плетневу> (условно датированного Гоголем временем получения в Женеве денежной помощи от Государя — «2 ноября 1837 г.»). В настоящем письме (так же, как в <Письме из Рима к редактору журнала «Современник» П.А. Плетневу >) Гоголь умалчивает, что посланные Государем деньги он получил не в Риме, а в Женеве ${ }^{12}$.

К той же дате - 30 ноября (н. ст.) 1837 г., — по-видимому, относится и недатированное письмо Гоголя к Н.Я. Прокоповичу ${ }^{13}$, которое ранее считалось написанным в Риме 2 ноября (н. ст.) 1837 г. ${ }^{14}$ Как уже указывалось, в Рим Гоголь прибыл только в конце ноября (н. ст.) 1837 г.

Месяцем ранее следует датировать письмо Гоголя к матери из Генуи 1838 г. Сам Гоголь сопроводил его пометой: «Генуя. Октября 13/1. 1838». В самом послании он сообщал: «Я пишу к вам на дороге, возвращаясь в Рим, куда надеюсь быть через четыре дня...» В обозначении месяца на письме Гоголь, судя по всему, ошибся, как это часто с ним случалось (см., в частности, ниже обоснование датировки письма Гоголя к матери от 26 августа (н. ст.) 1839 г.). Вместо ноября он написал октябрь, тогда как почти весь октябрь он определенно жил в Париже, а 28 октября (н. ст.) 1838 г. - на возвратном пути из Франции в Италию - был проездом в Лионе ${ }^{15}$. Исходя их этих соображений, письмо следует датировать $1 / 13$ ноября 1838 г.

Ошибка с обозначением месяца периодически появляется в заграничных письмах Гоголя вследствие часто возникавшей перед ним не-

11 Виноградов И.А. Летопись жизни и творчества Н.В. Гоголя (1809-1852). Т. 3. C. 71 .

${ }_{12}$ См.: Гоголь Н.В. Полн. собр. соч. и писем: В 17 т. Т. 11. С. 404.

13 См. там же.

14 Гоголь Н.В. Полн. собр. соч.: В 14 т. <Л.>, 1952. Т. 11 / Тексты и коммент. подгот. М.К. Азадовский, Ц.С. Вольпе, В.В. Гиппиус, Б.П. Городецкий, А.Г. Дементьев, С.Н. Дурылин, Л.В. Крестова, Н.Г. Машковцев, Н.И. Мордовченко, А.А. Назаревский, М.А. Панченко. С. 115, 389 (коммент. А.А. Назаревского).

15 Виноградов И.А. Летопись жизни и творчества Н.В. Гоголя (1809-1852). Т. 3. C. 143. 
обходимости перевода стилей — с русского на европейский и обратно. Живя «в двух измерениях», Гоголь порой сопровождает число «нового» стиля тем месяцем, который соответствует русскому календарю. При этом то и дело возникает путаница, поскольку в некоторых случаях (как в настоящем письме) Гоголь, помимо числа по западному летоисчислению, указывает еще и число русского стиля.

\section{7}

Аналогичную ошибку Гоголь допустил в письме к сестрам, написанном по прибытии в Рим осенью 1838 г. Так же, как в письме к матери из Генуи, Гоголь вместо ноября написал октябрь: «Рим. 15 октября». Наиболее вероятно, что письмо было написано в самый день приезда Гоголя в Рим 15 ноября (н. ст.) 1838 г. Примечательно, что ответ на письмо матери, - полученное так же, как письмо от сестер, сразу по приезде в Рим осенью 1838 г., — Гоголь помечает ноябрем: «Рим. Ноябрь, $1838 »$, - по-видимому, уже разобравшись в своей ошибке. Именно к ноябрю относится первое свидетельство о пребывании Гоголя в Риме осенью 1838 г., принадлежащее графу Мих. Ю. Виельгорскому. Последний в письме к В.А. Жуковскому от 20 ноября (н. ст.) 1838 г. сообщал: «Видел я Гоголя, которого можно назвать римским Гоголем. Он помолодел, об тебе много спрашивал и с нетерпением ожидает» ${ }^{16}$.

\section{8}

В новой точной датировке - 10 марта (н. ст.) 1839 г. (вместо прежней приблизительной: январь — май 1839 г. $^{17}$ ) — нуждается недатированное письмо Гоголя к П.Н. Демидову. Послание датируется на основании дневниковой записи М.П. Погодина от 10 марта (н. ст.) 1839 г.: «Письмо Демидова к Гоголю» ${ }^{18}$.

Впервые окончательно уточняется прежняя приблизительная датировка (май 1839 г. $)^{19}$ письма Гоголя к С.П. Шевыреву из Рима в Париж.

${ }^{16}$ Там же. С. 157.

17 См.: Гоголь Н.В. Полн. собр. соч.: В 14 т. Т. 11. С. 231.

18 См.: Гоголь Н.В. Полн. собр. соч. и писем: В 17 т. Т. 11. С. 210-211, 428; Виноградов И.А. Летопись жизни и творчества Н.В. Гоголя (1809-1852). Т. 3. С. 198, 244.

$19<$ Гоголь Н.В.> Соч. и письма Н.В. Гоголя. Изд. П.А. Кулиша. Т. 5. С. 371-372; $<$ Гоголь Н.В.> Письма Н.В. Гоголя. Ред. В.И. Шенрока. Т. 1. С. 603-604; Гоголь Н.В. Полн. собр. соч.: В 14 т. Т. 11. С. 233-234, 413-414 (коммент. А.Г. Дементьева). 
Письмо было начато накануне визита Гоголя к жене Шевырева, Софье Борисовне (которая с трехлетним сыном Борисом ${ }^{20}$ жила в Риме), и завершено после посещения Шевыревой, которая 20 мая (н. ст.) 1839 г. записала в дневнике: «20 сего месяйа. Продолжаю писать, начиная с 15го числа. <..> Четверг, $16<$ мая (н. ст.)>. На Вознесение сходила на мессу... <..> Утром получила письмо от мужа... <..> Вечером, когда я одевалась к ужину, пришел Гоголь. Из-за его визита Борис начал капризничать, и мне пришлось его даже отшлепать» ${ }^{21}$.

Вероятно, 3/15 мая 1839 г. - накануне праздника Вознесения Господня 4/16 мая - письмо от Шевырева из Парижа, с припиской М.П. Погодина, получил и Гоголь. Одновременно, в тот же день, Гоголем было получено и парижское послание А.С. Данилевского, с которым Шевырев и Погодин встречались в Париже.

На следующий день, накануне вечернего визита к Шевыревой, Гоголь стал писать ответные письма Данилевскому («Рим. Мая 16-го. Вчера я получил твое письмо...») и Шевыреву: «Благодарю тебя мильон раз за твое милое письмо...» Предварительно закончив - и даже подписав письмо к Шевыреву: «Прощай, мой милый и добрый. Твой Гоголь», Гоголь, однако, прежде чем отправить письма, решил тогда же навестить Софью Борисовну, чтобы поделиться с ней известиями о ее муже и, в свою очередь, сообщить ему сведения о ней.

После визита к Шевыревой Гоголь вновь обратился к письму к Шевыреву и дописал: «Письмо твое я получил только вчера. Четыре дня я не видал Софьи Борисовны... <...> София Борисовна, я нахожу, поправилась. Воздух здешней весны для нее, видно, очень хорош».

\section{0}

Тем же числом, 16 мая (н. ст.) 1839 г., следует датировать и письмо Гоголя к М.П. Погодину в Париж (прежняя приблизительная датировка: май-июнь $1839 \Gamma^{22}$ ). Гоголь отвечает в этом письме на ту приписку, которую Погодин сделал в письме Шевырева (получено Гоголем в Риме 15 мая (н. ст.) 1839 г.).

${ }^{20}$ «Шевырев, Борис Степанович, полковник, $\mathrm{p}<$ одился > 28 февраля $1836 \uparrow 29$ декабря 1888 (Казанское военное кладбище в Царском Селе)» (Великий Князь Николай Михайлович, Саитов В.И. Петербургский некрополь. СПб., 1912. Т. 4. С. 522).

21 Дневник Софьи Борисовны Шевыревой. Подгот. к публ. и коммент. А.А. Горохова, пер. с фр. М.О. Ноздренко // Историческое образование. 2014. № 4. C. 180 .

$22<$ Гоголь Н.В.> Соч. и письма Н.В. Гоголя. Изд. П.А. Кулиша. СПб., 1857. Т. 5. С. 376-377; <Гоголь Н.В.> Письма Н.В. Гоголя. Ред. В.И. Шенрока. Т. 1. С. 610 611; Гоголь Н.В. Полн. собр. соч.: В 14 т. Т. 11. С. 237-238, 414-415 (коммент. Б.П. Городецкого). 
Предлагается новая датировка двух писем Гоголя к матери 1839 г. Одно из этих писем сам Гоголь пометил: «Триест. 26 сентября», - однако написано оно было, очевидно, в Вене месяцем ранее, 26 августа (н. ст.) 1839 г. Вопреки реальному пребыванию в Вене Гоголь в письме матери сообщает: «Завтра отправлюсь в Вену...» Согласно письму Гоголя к С.П. Шевыреву от 25 августа (н. ст.) 1839 г., в Вену Гоголь прибыл уже 24 августа (н. ст.). До этого, а именно до 15 августа (н. ст.) 1839 г., Гоголь жил в Мариенбаде и, по его словам в письме к М.П. Погодину от того же числа, намеревался остаться там «еще недели на полторы», т.е. примерно до 25 августа. Если опираться на слова Гоголя в комментируемом письме к матери, что он «отправляется в Вену», то следует предположить, что вместо этого Гоголь поехал тогда в Триест, откуда и написал письмо, что маловероятно (сомнения подтверждает поддельный почтовый штемпель - «тонко нарисованный», по наблюдению С.Н. Дурылина, самим Гоголем $\left.{ }^{23}\right)$. Думается, письмо было написано уже по прибытии Гоголя из Мариенбада в Вену. Вместо августа Гоголь ошибочно написал сентябрь, так же как позднее считал сентябрь 1839 г. октябрем, чем, по-видимому, даже ввел в заблуждение Погодина, в свою очередь пометившего в дневнике сентябрьские события 1839 г. октябрем ${ }^{24}$. (Аналогичные случаи см. в обосновании датировок писем Гоголя к матери от 13 ноября (н. ст.) 1838 г. и от 22-24 сентября (н. ст.) 1839 г. В письме к С.П. Шевыреву от 10 сентября (н. ст.) 1839 г. Гоголь, напротив, вместо сентября пишет август: «Вена. 10 августа».)

Следующее письмо Гоголя к матери, от 27 августа (н. ст.) 1839 г., обозначено уже реальным местом отправления: «Вена. 1839, августа 28». Новым письмом Гоголь как бы ставил мать в известность, что он уже находится там, куда недавно обещал отправиться. При этом Гоголь исправляет ошибку в обозначении месяца (датирует новое письмо августом) и прибавляет для убедительности один день (датировав письмо 28-м числом, вместо действительного 27-го, что явствует из почтового штемпеля), чтобы время его выдуманного переезда из Триеста в Вену выглядело более реальным, т.е. не казалось слишком скорым. Причины, по которым Гоголь прибегнул к этим ухищрениям, остаются недостаточно ясными. В.И. Шенрок, полагавший (ошибочно), что письмо было написано 26 сентября (ст. ст.) 1839 г. в Москве, высказал мнение, будто C. 420 .

${ }^{23}$ См. коммент. в изд.: Гоголь Н.В. Полн. собр. соч.: В 14 т. <Л.>, 1952. Т. 11.

${ }^{24}$ См.: Гоголь в воспоминаниях, дневниках, переписке современников. Полный систематический свод документальных свидетельств. Научно-критическое изд. / Изд. подгот. И.А. Виноградов. В 3 т. М., 2012. Т. 2. С. 462-463. 
Гоголь опасался, чтобы его мать, «сильно жаждавшая повидаться с ним, не приехала слишком рано к Погодину, тогда как Гоголю и без того неловко было помещать на долгое время у него всю семью» ${ }^{25}$. Можно допустить, что эта мысль стала беспокоить Гоголя еще в Вене, где он в течение месяца ожидал встречи с Погодиным, чтобы вернуться вместе с ним в Россию. (Расставшись 8 августа (н. ст.) 1839 г. в Мариенбаде, Гоголь и Погодин условились встретиться в Вене; встреча произошла 19 сентября (н. ст.). 1839 г.) В последующих письмах к матери - от 22-24 сентября (н. ст.) и от 26 сентября (н. ст.) 1839 г. - Гоголь также как бы «оттягивает» время своего возращения в Россию: будучи уже в дороге, сообщает матери, что он только выезжает из Вены. Возможно, это в свою очередь связано с опасением Гоголя, чтобы мать не приехала в Москву раньше срока - до того, как он заберет сестер из Петербурга. «...Я не хочу вас льстить напрасною надеждою, - замечает Гоголь в письме. - Может быть, увидимся нынешнюю зиму, может быть нет. Если ж увидимся, то не пеняйте, что на короткое время». Далее он добавляет: «...не примите опять этого адреса в том смысле, чтобы я был скоро в Москве...»

\section{2}

Второе письмо Гоголя к матери 1839 г., нуждающееся в новой датировке, было начато 22 сентября (н. ст.) 1839 г. в Вене и отправлено 24 сентября (н. ст.) из Ольмюца. Сам Гоголь ошибочно датировал письмо октябрем: «Октябрь 24. Вена».

Встретившись с М.П. Погодиным в Вене вечером 19 сентября (н. ст.) 1839 г., Гоголь пробыл с ним там до 22 сентября (н. ст.), после чего они выехали в Краков. В Кракове они пробыли два дня - 25 и 26 сентября (н. ст.) 1839 г. ${ }^{26}$ Таким образом, 24 сентября (н. ст.) 1839 г. Гоголя и Погодина уже не было в Вене - они находились проездом в Ольмюце. По-видимому, там Гоголь и отправил свое письмо к матери, начатое в Вене.

Примечательно, что в дневнике Погодина все эти дни ошибочно помечены не сентябрем, а октябрем 1839 г.: «Возвратный путь. < ..> Октябрь 12/24 - ноябрь 20 с<тарого $>$ с $<$ тиля $>)^{27}$. По-видимому, именно Гоголь, порой ошибочно обозначавший месяца и числа в датах отправления своих писем, ввел Погодина в заблуждение (см. выше), а также неверно датировал свое сентябрьское письмо к матери октябрем.

\footnotetext{
$25<$ Гоголь Н.В. $>$ Письма Н.В. Гоголя. Ред. В.И. Шенрока. Т. 2. С. 10.

${ }^{26}$ Виноградов И.А. Летопись жизни и творчества Н.В. Гоголя (1809-1852). Т. 3. C. $290-294$.

$27<$ Погодин М.П.> Год в чужих краях. Дорожный дневник М. Погодина. М., 1844. Ч. 4. C. 222.
} 
В эпистолярном наследии Гоголя долгое время оставалась неизученной история одной короткой записки, точнее, визитки с надписью: «Визит отдадите в Риме № 126, Via Felice». Предложенная в 1952 г. Г.М. Фридлендером датировка охватывает период около шести лет с октября 1837 по апрель $1843 г^{28}{ }^{28}$ На протяжении этого времени Гоголь жил в Риме по указанному на визитке адресу: улица Феличе, дом 126.

Как выясняется, записка была адресована московскому знакомому Гоголя с 1835 г., путешественнику и литератору Николаю Петровичу Боткину. Перед отъездом за границу весной 1840 г. Гоголь искал попутчика, о чем дал объявление, напечатанное трижды, 6, 10 и 17 апреля 1840 г., в «Московских Ведомостях»: «Некто, не имеющий собственного экипажа, ищет попутчика до Вены, имеющего собственный экипаж...» Хотя в дорогу Гоголь отправился тогда с В.А. Пановым (изъявившим желание быть спутником Гоголя 13 апреля 1840 г.), однако именно Н.П. Боткин оказался позднее с Гоголем в Вене во второй половине - конце августа (н. ст.) 1840 г., во время тяжелой болезни писателя (в то время как Панов 11 июля (н. ст.) 1840 г. выехал из Вены в Мюнхен, условившись с Гоголем встретиться вновь в Венеции). 2 сентября (н. ст.) 1840 г. Н.П. Боткин приехал вместе с Гоголем в Венецию, а затем с Гоголем и Пановым прибыл 25 сентября (н. ст.) в Рим.

Судя по всему, Н.П. Боткин, получив в Москве в средине мая 1840 г.

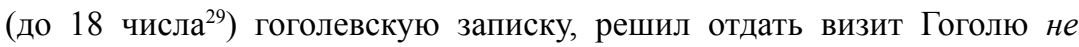
в Риме, а догнать его еще по дороге в Италию. О намерении Гоголя остановиться по пути в Рим в Вене Н.П. Боткин мог знать как от самого писателя, так и из упомянутого газетного объявления или от общих знакомых. О своих планах задержаться в Вене Гоголь, в частности, сообщал в 1840 г. в письмах из Москвы к В.А. Жуковскому от 3 мая и к матери от 17 мая, а также в письмах из Варшавы в Москву к М.П. Погодину от конца мая - начала июня (н. ст.) и к С.Т. Аксакову от 10 июня (н. ст.). 28 июня (н. ст.) 1840 г. Гоголь писал в Москву из самой Вены А.П. Елагиной: «Кто вздумает писать ко мне, тот да адресует в Вену в poste restante. Я здесь пробуду месяца полтора - пью воды. В сентябре же месяце адрес мой в Рим тоже poste restante».

Гоголевскую записку Н.П. Боткин перед отъездом из Москвы подарил своему брату, Василию Петровичу Боткину, который осенью того же

${ }^{28}$ См.: Гоголь Н.В. Полн. собр. соч.: В 14 т. <Л.>, 1952. Т. 12 / Тексты и коммент. подгот. Р.Б. Заборова, А.Н. Михайлова, А.А. Назаревский, Г.М. Фридлендер. С. 624.

${ }^{29}$ День отъезда Гоголя из Москвы. 
1840 г. побывал в Харькове и показывал ее там харьковскому писателю и переводчику А.Я. Кульчицкому ${ }^{30}$.

\section{4}

Целым годом позже следует датировать шутливое письмо Гоголя Е.Г. Чертковой из Вены в Москву. Письмо имеет помету без указания года: «Вена. Июня 22». Впервые оно было напечатано П.И. Бартеневым без уточнения датировки ${ }^{31}$. Впоследствии В.И. Шенроком письмо было оставлено недатированным, однако включено в ряд писем 1839 г. ${ }^{32}$ (что равносильно датировке письма 1839 г.). Вслед за Шенроком М.А. Панченко также ошибочно отнес письмо к 1839 г. ${ }^{33}$ Между тем 22 июня 1839 г. Гоголя в Вене не было, он был тогда в Марселе (куда прибыл из Рима). В 1839 г. в Вену Гоголь приехал лишь 24 августа (н. ст.). Письмо, очевидно, относится к следующему, 1840 г., когда Гоголь провел в Вене почти всё лето, с 17 июня (н. ст.) до конца августа (н. ст.), прибыв сюда из Москвы, где, в числе других знакомых, общался с Чертковой.

\section{5}

Исправляется датировка письма Гоголя к сестре Елисавете от 7 июля (н. ст.) 1840 г. из Вены, в котором он упрекает ее в мнительности, «когда дело идет» об ее здоровье. Ранее ошибочно считалось, что это письмо было написано в Москве в период с 10 по 18 мая 1840 г. ${ }^{34}$ Между тем письмо, безусловно, было отправлено из Вены, где до этого Гоголь ожидал письма от сестры (см. письмо к ней от 25 июня (н. ст.) 1840 г.). 5 июля (н. ст.) 1840 г. он наконец получил послание из Москвы от С.Т. Аксакова с вложением письма от сестры (последнее письмо не сохранилось). Аксаков сообщал Гоголю: «Лиза ваша здорова, начинает привыкать к новому своему житью-бытью и хорошо улаживается. <...> Она гостит у нас другой день... <..> Лиза сама пишет». Месяц спустя, в письме к матери

${ }^{30}$ См. подробнее: Виноградов И.А. Гоголь на пути в Рим в 1840 г. Из истории общения писателя с современниками // Гоголезнавчі студіі. Гоголеведческие студии. Ніжин, 2014. Вып. 4 (21). С. 12-18; Виноградов И.А. «Хаос» в Ватикане. К истории одного из путешествий Гоголя // Восток и Запад в русской литературе путешествий XI-XX вв. М.: ИМЛИ РАН (в печати).

$31<$ Бартенев П.И.> Шуточное письмо Н.В. Гоголя к одной русской даме. Вена, Июня 22 // Русский Архив. 1867. Стб. 473-475.

$32<$ Гоголь Н.В.> Письма Н.В. Гоголя. Ред. В.И. Шенрока. Т. 1. С. 617-618.

${ }^{33}$ См.: Гоголь Н.В. Полн. собр. соч.: В 14 т. Т. 11. С. 414.

${ }^{34}$ См.: $<$ Гоголь Н.В.> Соч. и письма Н.В. Гоголя. Изд. П.А. Кулиша. Т. 5. С. 396397; < Гоголь Н.В.> Письма Н.В. Гоголя. Ред. В.И. Шенрока. Т. 2. С. 42-43; Гоголь Н.В. Полн. собр. соч.: В 14 т. Т. 11. С. 285, 433 (коммент. А.А. Назаревского). 
от 7 августа (н. ст.) 1840 г. из Вены, Гоголь упоминал о письмах, которые получает от сестры из Москвы. Там же Гоголь говорил о сообщении сестры (в ее письме к матери) о болезни, случившейся с Елисаветой после прощания с Гоголем 18 мая 1840 г.: «...Она по безрассудности своей в ту же минуту написала письмо, а к этому присоединила и грудную боль, что натурально ложь. Потому что от Аксакова я сию минуту получил письмо, что она потолстела. Да и сама она ко мне пишет, что несмотря на свое горе толстеет и боится чрезвычайно сделаться Щепкиным и все платья нужно было ей переправлять. Вот какого рода ее грудная боль!» (По-видимому, приводя в письме «свидетельство» Аксакова, что сестра «потолстела», Гоголь таким образом «пересказывает» краткое аксаковское сообщение о том, что «Лиза $<\ldots$..> здорова».) Таким образом, письмо от сестры, очевидно, было получено Гоголем 5 июля (н. ст.) 1840 г. вместе с письмом С.Т. Аксакова, а ответ, в свою очередь, по-видимому, был приложен к ответному письму Аксакову от 7 июля (н. ст.) 1840 г.

\section{6}

Из писем 1840 г. уточнения датировок требуют еще четыре послания Гоголя из Венеции. Во-первых, это еще одно письмо к сестре Елисавете. Год и место отправления, выставленные на письме: «Венеция 1840. Август 10». Это указание свидетельствует, что письмо могло быть написано только в период пребывания Гоголя в Венеции с 2-го по начало двадцатых чисел сентября (н. ст.) 1840 г. Августом это сентябрьское письмо помечено Гоголем ошибочно; подобная ошибка часто встречается в его корреспонденции и связана с неверным осмыслением календаря при пересчете разницы между европейским и русским стилями летоисчисления (см., в частности, выше обоснование датировки письма Гоголя к матери от 26 августа (н. ст.) 1839 г.). Датировка указанного письма сентябрем (10 числа н. ст.), а не августом, как у Гоголя, была справедливо предложена в свое время А.И. Кирпичниковым ${ }^{35}$. Аргументы А.Г. Дементьева, не соглашавшегося с этой датировкой ${ }^{36}$, представляются нам неубедительными. Намерение быть в Риме «в конце этого месяца», сообщаемое в конце настоящего письма к сестре, в точности исполняется (если опираться на предложенную датировку) с приездом Гоголя в Рим 25 сентября (н. ст.) 1840 г. Сообщение Гоголя в этом же письме о своем здоровье: «Оно точно было плохо, и я захворал было не на шутку», - соответ-

35 См.: Кирпичников А.И. Сомнения и противоречия в биографии Гоголя. (Комментарий к биографической канве его) // Известия Отделения Русского языка и словесности Императорской Академии наук. 1900. Т. 5. № 4. С. 1212-1235.

${ }^{36}$ См. коммент. в изд.: Гоголь Н.В. Полн. собр. соч.: В 14 т. Т. 11. С. 437. 
ствует данным о его болезни в Вене, откуда он уехал в конце августа (н. ст.) 1840 г. Средством исцеления от недуга послужил тогда Гоголю, по его собственному свидетельству, именно переезд - из Вены в Триест (неподалеку от Венеции) и далее в Венецию и Рим: «Я велел себя посадить в дилижанс и везти в Италию. Добравшись до Триэста, я себя почувствовал лучше. Дорога, мое единственное лекарство, оказала и на этот раз свое действие» (письмо к М.П. Погодину от 29 октября (н. ст.) 1840 г. из Рима). Всё это противоречит попыткам отнести написанное Гоголем в Венеции письмо ко времени его пребывания в Вене, тем более что тогда к «вопросу, почему Гоголь вместо Вены указал Венецию, трудно привести убедительные соображения» ${ }^{37}$.

\section{7}

Изложенные аргументы полностью применимы и к письму Гоголя М.П. и Е.В. Погодиным с аналогичной пометой: «Август 10. Венеция». Письмо было отправлено из Венеции 10 сентября (н. ст.) 1840 г.

\section{8}

Это же относится к посланию Гоголя к О.Сем. Аксаковой с пометой: «Венеция. Август 10». К этому письму было приложено упомянутое выше гоголевское послание к сестре от 10 сентября (н. ст.) 1840 г. с аналогичным указанием: «Венеция 1840. Август 10». Гоголь сообщал Аксаковой: «Отправьте прилагаемое при сем письмо к Лизе и вручите Михаилу Семеновичу прилагаемое при сем действие переведенной для него комедии» (речь идет о переводе комедии Дж. Жиро «Дядька в затруднительном положении»).

\section{9}

Согласно приведенным выше строкам из письма Гоголя к Аксаковой, к 10 сентября (н. ст.) 1840 г. следует отнести и недатированное письмо к М.С. Щепкину, в котором Гоголь отправил актеру перевод комедии Дж. Жиро. Традиционно это письмо также ошибочно датировали 10 августа (н. ст.) 1840 г. — временем пребывания Гоголя в Вене $\mathrm{e}^{38}$.

\footnotetext{
37 Там же. С. 437.
}

38 См.: <Гоголь Н.В.> Соч. и письма Н.В. Гоголя. Изд. П.А. Кулиша. Т. 5. С. 409-412; <Гоголь Н.В.> Письма Н.В. Гоголя. Ред. В.И. Шенрока. Т. 2. С. 61; Гоголь Н.В. Полн. собр. соч.: В 14 т. Т. 11. С. 304. 
Январем-апрелем 1841 г. неточно датировалась до настоящего времени римская записка Гоголя, адресованная А.А. Иванову, в которой он приглашает художника, вместе с Н.П. Боткиным, В.А. Пановым и Ф.И. Иорданом, к себе в гости ${ }^{39}$. Поскольку с февраля (н. ст.) 1841 г. Панов переехал на квартиру Гоголя ${ }^{40}$, звать его к себе в то время Гоголь уже не мог. Таким образом, записку следует датировать периодом с 25 сентября (н. ст.) 1840 г. (время приезда в Рим Гоголя, Боткина и Панова) до января (н. ст.) 1841 г.

\section{1}

Требует существенного уточнения датировка еще одного письма Гоголя к сестре Елисавете, в котором содержится поручение купить для него и «изрубить в куски» 3 фунта (т.е. около полутора килограмм) сахару, а также приобрести 2 фунта (около килограмма) свечей и фунт (почти полкилограмма) кофе. Следуя датировке П.А. Кулиша ${ }^{41}$, Шенрок отнес это письмо к последней неделе пребывания Гоголя в Москве в 1840 г. — «к промежутку от 10 до 17 мая 1840 г., когда Гоголь был на отъезде (он выехал 18 мая) и уже поместил сестру у Раевской, что было 10 мая» ${ }^{42}$. Между тем Гоголю вряд ли могли понадобиться столь существенные запасы всего на несколько дней перед отъездом. С другой стороны, хозяйственное поручение Гоголя предполагает известную самостоятельность сестры, каковой она, учитывая шестнадцатилетний возраст и вынесенную из института крайнюю застенчивость ${ }^{43}$, точно не могла иметь в 1840 г. Вероятнее всего, записка Гоголя к сестре была написана в средине ноября 1841 г. - после полутора лет проживания Елисаветы Васильевны в Москве, когда осенью этого года она принялась за переписку последних восьми глав цензурного экземпляра «Мертвых душ» $\rangle^{44}$.

39 См.: Гоголь Н.В. Полн. собр. соч.: В 14 т. Т. 11. С. 338 (коммент. Н.Г. Машковцева). Впервые записка была опубликована, без датировки, П.А. Кулишом: Кулиш П.А. Переписка Н.В. Гоголя с А.А. Ивановым. (Посвящается Федору Ивановичу Иордану) // Современник. 1858. № 11. С. 128. C. 495 .

Виноградов И.А. Летопись жизни и творчества Н.В. Гоголя (1809-1852). Т. 3.

$41<$ Гоголь Н.В.> Соч. и письма Н.В. Гоголя. Изд. П.А. Кулиша. Т. 5. С. 396.

42 См.: <Гоголь Н.В.> Письма Н.В. Гоголя. Ред. В.И. Шенрока. Т. 2. С. 42.

${ }^{43}$ См.: Виноградов И.А. Летопись жизни и творчества Н.В. Гоголя (1809-1852). T. 3. C. 354 .

${ }^{44}$ См.: Там же. С. 607-608. 
Весьма широким - тоже шестилетним - периодом, с 1837 по 1843 г., была датирована Г.М. Фридлендером в 1952 г. следующая записка Гоголя к неустановленному лицу: «Нельзя ли отправить это письмецо к Розенштрему [вместе с деньгами] с тем, чтобы оно было включено в пакет вместе с векселем к Валентини» ${ }^{45}$.

Основанием для крайней даты записки (1843 г.) послужило то, что упоминаемый в ней римский банкир Д. фон Валентини умер весной-летом 1842 г. (о его кончине С.Т. Аксаков известил Гоголя в письме от 6 июля 1842 г.46; сам Гоголь упоминает о смерти банкира в письме к А.А. Иванову от 30 августа (н. ст.) 1842 г.). Еще раз о Валентини Гоголь пишет в послании к С.П. Шевыреву, отправленном из Рима от 28 февраля (н. ст.) 1843 г.: «...Если набрались деньги, то высылай их немедленно на имя Валентини, piazza Apostoli, palazzo Valentini...» (Возможно, речь в данном письме шла уже о наследнике Д. фон Валентини.)

Упоминание в записке Розенштрема, еще одного банкира - московского, позволяет существенно сократить временной промежуток, в который Гоголь мог набросать записку. Вероятно, непосредственное к ней отношение имеет предваряющая гоголевская заметка для памяти, сделанная в записной книжке 1841-1845 гг.: «К Розенштр<ему>».

Основанием для еще более точной датировки служит то, что посылаемые в Рим деньги предназначались для А.А. Иванова ${ }^{47}$, который и получил их 7-11 февраля 1842 г. от банкира Д. фон Валентини ${ }^{48}$. Таким образом, комментируемая записка, несомненно, относится к концу декабря 1841 г. Дополнительным подтверждением этой датировки служит письмо Гоголя к Иванову, традиционно приурочиваемое к этому времени - концу декабря 1841 г. По всей вероятности, это то самое «письмецо», о котором Гоголь упоминает в записке к неизвестному («Нельзя ли отправить это письмецо к Розенштрему [вместе с деньгами]...»). (О том, что за письмо имеет в виду Гоголь в записке, в комментарии Г.М. Фридлендера не сообщается.) В «письмеце» Гоголь сообщает Иванову: «Вот вам деньги для расплаты моих долгов». (Лицом, которого Гоголь просил доставить Розенштрему письмо к Иванову, мог быть либо М.П. Погодин, либо С.П. Шевырев.)

${ }^{45}$ Гоголь Н.В. Полн. собр. соч.: В 14 т. <Л.>, 1952. Т. 12 / Тексты и коммент. подгот. Р.Б. Заборова, А.Н. Михайлова, А.А. Назаревский, Г.М. Фридлендер. С. 635 (коммент. Г.М. Фридлендера). C. 146 .

46 Виноградов И.А. Летопись жизни и творчества Н.В. Гоголя (1809-1852). Т. 4.

47 Там же. Т. 3. С. 600, 616-617.

48 Там же. T. 4. C. 20-21. 
Случай, во многом аналогичный ошибочной датировке письма Гоголя к сестре Елисавете от средины ноября 1841 г. (см. выше), представляет собой неверное временное приурочение еще одной записки к ней, в которой Гоголь сообщает: «В воскресенье приезжай ко мне. А до того вряд ли мне удастся быть у вас. Я вчера у Аксаковых в силу мог двигаться».

В.И. Шенрок, следуя опять-таки датировке П.А. Кулиша ${ }^{49}$, в свою очередь относил эту записку «к промежутку от 10 до 17 мая 1840 г., когда Гоголь был на отъезде (он выехал 18 мая) и уже поместил сестру у Раевской, что было 10 мая» ${ }^{50}$. Однако если бы такая догадка была верна, то упоминаемое в записке воскресенье («В воскресенье приезжай ко мне») должно приходиться точно на 12 мая 1840 г. Поскольку Гоголь перевез сестру к П.И. Раевской 10 мая, то единственно возможной датой отправления письма становится, таким образом, 11 мая 1840 г. Последнее невозможно по двум причинам. Во-первых, приглашая сестру в гости на следующий день, Гоголь, скорее всего, написал бы: «Завтра приезжай ко мне» (а не - «В воскресенье приезжай ко мне»). Во-вторых, сообщение в письме: «Я вчера у Аксаковых в силу мог двигаться», - отсылает (если принять датировку 11 мая) к тому дню, когда Гоголь отвез сестру к Раевской, т.е. к 10 мая. Но известно, что вечер этого дня Гоголь провел не у Аксаковых, а у Свербеевых ${ }^{51}$. Таким образом, единственно возможным представляется датировать записку Гоголя не 1840 г., а 1841-1842 гг., а именно, периодом следующего совместного пребывания Гоголя и его сестры в Москве с 17 октября 1841 по 23 мая 1842 г. В этот период обострение болезненного состояния Гоголя определенно приходилось на январь 1842 г. Так, в письме к князю В.Ф. Одоевскому между 2 и 7 января 1842 г. он замечал: «...Я очень болен и в силу двигаюсь» (ср. в записке к сестре: «Я вчера <..> в силу мог двигаться»); в письме к Н.Я. Прокоповичу между 22 и 27 января 1842 г. вновь сообщал: «Так устал от писем и всяких тревог душевных и телесных и, от болезни моей, которой припадки были теперь сильнее, нежели когда-нибудь, что руки не поднимаются». Таким образом, записку следует датировать первой половиной января 1842 г.

$49<$ Гоголь Н.В. $>$ Соч. и письма Н.В. Гоголя. Изд. П.А. Кулиша. Т. 5. С. 396.

$50<$ Гоголь Н.В.> Письма Н.В. Гоголя. Ред. В.И. Шенрока. Т. 2. С. 42 . См. также: Гоголь Н.В. Полн. собр. соч.: В 14 т. Т. 11. С. 285, 433 (коммент. А.А. Назаревского).

${ }^{51}$ См.: Виноградов И.А. Летопись жизни и творчества Н.В. Гоголя (1809-1852). T. 3. C. 433 . 
Написанным полутора годами позже следует считать письмо Гоголя к А.П. Елагиной, начинающееся словами: «Передаю вам в ваши руки Языкова», — которое М.А. Панченко в издании 1952 г. ошибочно отнес к концу 1841 г. — времени пребывания Гоголя в Москве ${ }^{52}$.

Послание к Елагиной, безусловно, написано 8 июля (н. ст.) 1843 г. в Баден-Бадене. Это то самое послание, о котором упоминает Гоголь в письме к Н.М. Языкову от 8 июля (н. ст.) 1843 г., отправленном в Дрезден: «Это маленькое письмецо отдай Элагиной». Комментируя эти строки, Г.М. Фридлендер ошибочно полагал: «Письмецо Гоголя к А.П. Елагиной неизвестно» ${ }^{53}$.

В записке Гоголь поручал отправлявшегося в Россию больного Языкова заботам Елагиной - и просьбу к ней об этом вложил в письмо к самому Языкову. В письме к нему Гоголь замечал: «Из письма твоего ко мне в Эмс ${ }^{54}$ вижу, что ты решительно хочешь ехать домой ${ }^{55}$. Если так, то да благословит тебя Бог». «Передавая» Языкова «в руки» Елагиной, Гоголь писал: «Отыщите для него квартиру сами, не менее пяти или, по крайней мере, четырех комнат. Две из них чтобы были большие» и пр. Согласно почтовому штемпелю на послании к Языкову ${ }^{56}$, оба письма были отправлены из Баден-Бадена в Дрезден на следующий день, 9 июля (н. ст.) 1843 г.

\section{5}

2 февраля (н. ст.) 1844 г. ошибочно датировано письмо Гоголя к С.П. Шевыреву в Москву, имеющее авторскую помету: «Ниц<ц>а. Февраль 2 1844». (Послание является ответом на письмо Шевырева от 27 октября 1843 г.) Ошибка комментатора, Г.М. Фридлендера ${ }^{57}$, заключается в том, что самим Гоголем дата приведена не по новому, а по старому стилю. Между тем письмо имеет почтовый штемпель: «Nizza 14 Fev» ${ }^{58}$, следовательно, написано оно было 2/14 февраля. Допущенная невни-

${ }^{52}$ Гоголь Н.В. Полн. собр. соч.: В 14 т. Т. 11. С. 356, 454.

53 Там же. Т. 12. С. 629.

54 Письмо не сохранилось.

55 См.: Виноградов И.А. Летопись жизни и творчества Н.В.Гоголя (1809-1852). Т. 4. С. 289-291. Языков приехал на жительство в Москву 31 июля 1843 г. (Там же. C. 391).

${ }^{56}$ См.: Городецкий Б.П. Описание автографов Н.В. Гоголя в собрании Института Литературы Академии Наук СССР // Литературный архив. Материалы по истории литературы и общественного движения. 1938. Т. 1. С. 471.

57 Гоголь Н.В. Полн. собр. соч.: В 14 т. Т. 12. С. 250.

58 Городеикий Б.П. Описание автографов Н.В. Гоголя в собрании Института Литературы Академии Наук СССР. С. 467. 
мательность тем более досадна, что на 2 февраля приходится праздник Сретения Господня, так что, поставив дату по старому стилю, Гоголь, по-видимому, желал обратить внимание адресата на праздничный день отправления письма. Об этом свидетельствует отправление Гоголем в тот же день еще двух важных писем к его московским друзьям (см. ниже).

\section{6}

В упомянутом праздничном послании к С.П. Шевыреву от 2/14 февраля 1844 г. Гоголь писал: «...Вы все, то есть и ты, и Погодин, и Аксаков, терпите часто душевные беспокойства и тревоги. $<\ldots>$ Я посылаю вам одно средство, уже мною испытанное, которое верно вам поможет уходить чаще в себя, а с тем вместе противиться всем душевным беспокойствам. При письме этом я прилагаю письмо ко всем вам. Ты прочитай его теперь же (прежде один) и купи немедленно во французской лавке четыре миниатюрные экземпляр<ч>ика Подражания Христу ${ }^{59}$, для тебя, Погодина, С.Т. Аксакова и Языкова».

Приложенное Гоголем к этому посланию общее письмо к С.Т. Аксакову, М.П. Погодину и С.П. Шевыреву имеет помету: «Генварь, 1844-го г. Ниц<ц>а». С этой авторской пометой оно и было напечатано в академическом издании $1952 \Gamma^{60}{ }^{60}$ Очевидно, однако, что его датировку также следует уточнить, приурочив его к периоду между январем и 14 февраля (н. ст.) 1844 г. В общем послании Гоголь писал: «...Вы часто бываете неспокойны духом. < ..> Я посылаю вам Подражание Христу...»

Еще одно письмо, отправленное Гоголем из Ниццы в Москву в праздничный день Сретения Господня, 14 февраля (н. ст.) 1844 г., послание к М.П. Погодину (в нем Гоголь тоже призывает друга читать «Подражание Иисусу Христу»). Самим Гоголем письмо к Погодину не датировано, но тоже имеет почтовый штемпель «Nizza 14 Fev» ${ }^{61}$. На этом основании Г.М. Фридлендер справедливо отнес письмо к этому числу ${ }^{62}$. Однако в целом в издании 1952 г. письма, написанные в один день - объединенные единым замыслом (заключающие в себе вразумления друзей

${ }^{59}$ Позднее книгу «Подражание Иисусу Христу» (приписываемую обычно Фоме Кемпийскому) Гоголь подарил также А.А. Иванову (см. письмо художника к Гоголю от сентября (н. ст.) 1846 г.), рекомендовал А.О. Смирновой (см. письмо к ней от 9 января (н. ст.) - 15 марта (н. ст.) 1845 г.) и графу А.П. Толстому (см. письмо Толстого к Гоголю от 12 декабря (н. ст.) 1844 г.). На “Imitation de Jésus Christ” Гоголь ссылался и в письме к П.А. Плетневу от первой половины декабря (н. ст.) 1844 г.

${ }^{60}$ Гоголь Н.В. Полн. собр. соч.: В 14 т. Т. 12. С. 249.

61 Городецкий Б.П. Описание автографов Н.В. Гоголя в собрании Института Литературы Академии Наук СССР. С. 462.

62 Гоголь Н.В. Полн. собр. соч.: В 14 т. Т. 12. С. 257. 
на праздник Сретения Господня), оказались произвольно оторванными друг от друга.

\section{7}

Ошибочно предложенное в 1952 г. А.Н. Михайловой указание на место и дату отправления письма Гоголя к графине С.М. Соллогуб в Петербург 1845 г.: «Лето - октябрь 1845. Рим» ${ }^{63}$. На самом деле письмо отправлено Гоголем из Парижа в период проживания его там с 14 января (н. ст.) до 1 марта (н. ст.) 1845 г. В то время Гоголь встречался в Париже с графинями Л.К. и Анной М. Виельгорскими ${ }^{64}$ - матерью и сестрой Соллогуб (урожд. графини Виельгорской). На это общение он указывает в письме к Соллогуб, имея в виду исполнение корреспонденткой добрых дел по его наставлениям ${ }^{65}$ : «Правда ли то, что вы уже несколько раз бросили копейку нищему? Мне по крайней мере так сказала Анна Миха <й >ловна».

Кроме того, в письме есть также строки, которые позволяют датировать послание еще более точно. Вероятно, оно было отправлено 24 февраля (н. ст.) 1845 г. - одновременно с письмом в Петербург к А.О. Смирновой, которая, в свою очередь, упоминается в послании: «Помогите особенно Александре Осиповне, когда увидите ее в хандре».

С предложенной датировкой вполне согласуется ответное письмо Гоголю графини Соллогуб, которое та отправила ему из Петербурга в день Пасхи 15/27 апреля 1845 г. ${ }^{66}$

\section{8}

Требует уточнения датировка новогоднего поздравления Гоголя Н.Н. Шереметевой, которое В.И. Шенроком было ошибочно отнесено ко второй половине декабря 1847 г. - времени проживания Гоголя в Неапо$л^{67}$. В действительности поздравление написано двумя годами ранее, 27 декабря 1845 г., в Риме. Основанием для новой датировки служит ответное письмо Шереметевой к Гоголю от 30 января 1846 г., в котором та сообщает

\footnotetext{
${ }^{63}$ Там же. С. $533,685$.

64 Виноградов И.А. Летопись жизни и творчества Н.В. Гоголя (1809-1852). Т. 5. C. $8-9,14,23,29,31,34-35,38-39$.

65 См., в частности, письмо Гоголя к графине С.М. Соллогуб от 24 сентября (н. ст.) 1844 г. C. 87

66 Виноградов И.А. Летопись жизни и творчества Н.В. Гоголя (1809-1852). Т. 5.

${ }^{67}$ См.: <Гоголь Н.В.> Письма Н.В. Гоголя. Ред. В.И. Шенрока. Т. 4. С. 133-134. См. также: Гоголь Н.В. Полн. собр. соч.: В 14 т. <Л.>, 1952. Т. 13 / Тексты и коммент. подгот. А.Н. Михайлова, Г.М. Фридлендер. С. 420, 533 (коммент. А.Н. Михайловой).
} 
о получении его письма через Н.М. Языкова. В свою очередь, Языков в послании к Гоголю из Москвы от 27 января 1846 г. замечал: «Н.Н. Шереметева < .. > поправляется; письмо твое послал я к ней в Рузу». Кроме того, неполный адрес на письме («Надежде Николаевне Шереметьевой») указывает, что гоголевское поздравление Шереметевой с новым годом было вложено в другое письмо. Таким письмом, по-видимому, и было послание Гоголя к Языкову из Рима в Москву от 27 декабря 1845 / 8 января (н. ст.) 1846 г., в котором Гоголь также передавал приятелю новогоднее поздравление. (Coгласно почтовому штемпелю на послании к Языкову: «Roma 10 gen. 46» ${ }^{68}$, оба письма были отправлены через день, 10 января (н. ст.) 1846 г.)

\section{9}

Датированная ранее двухмесячным периодом - от средины октября до средины декабря 1848 г. — записка Гоголя к его земляку А-ру Мих. Марковичу $^{69}$ определенно относится к 11 ноября 1848 г. Она связана с торжественным (в честь приезда Гоголя) празднованием дня рождения М.П. Погодина. Именно на этот «раут» 11 ноября 1848 г. Гоголь и пригласил Марковича, чтобы осмотреть погодинское «Древлехранилище» и увидеть «почти всех замечательных московских литераторов и ученых».

\section{0}

Тремя годами ранее следует датировать письмо Гоголя к протоиерею Матфею Константиновскому, начинающееся словами: «Граф А<лександр $>$ П<етрович $>$ Толстой передал мне ваш поклон и рассказал мне о своем душеусладном пребывании у вас во Ржеве». Послание имеет помету Гоголя: «28 ноября. Москва». П.А. Кулиш ${ }^{70}$ и вслед за ним В.И. Шенрок ${ }^{71}$ (а также А.Н. Михайлова ${ }^{72}$ ) без объяснений датировали письмо 1851 г. Между тем есть достаточные основания отнести его к 1848 г.

Согласно письму О.Сем. Аксаковой к сыну Ивану в Одессу, отправленному в тот же день, 28 ноября 1848 г., граф А.П. Толстой появился в Москве именно в это время (он приехал из Петербурга в Москву, очевидно, через Ржев). Именно тогда Гоголь с ним встречался, догово-

${ }^{68}$ Городецякий Б.П. Описание автографов Н.В. Гоголя в собрании Института Литературы Академии Наук СССР. С. 474.

69 Гоголь Н.В. Полн. собр. соч.: В 14 т. <Л.>, 1952. Т. 14 / Тексты и коммент. подгот. А.Н. Михайлова. С. 100, 386.

${ }^{70}<$ Гоголь Н.В.> Соч. и письма Н.В. Гоголя. Изд. П.А. Кулиша. Т. 6. С. 546

$71<$ Гоголь Н.В.> Письма Н.В. Гоголя. Ред. В.И. Шенрока. Т. 4. С. 412.

72 См.: Гоголь Н.В. Полн. собр. соч.: В 14 т. Т. 14. С. 259, 436. 
рившись о переезде от М.П. Погодина в дом графа ${ }^{73}$. «Гоголь $<\ldots>$ переезжает жить к Толстому...» - сообщала Аксакова сыну ${ }^{74}$.

Признание Гоголя в комментируемом послании к о. Матфею, что он «перечитывает» два его «последние» письма, перекликается со строками письма Гоголя к священнику от 12 сентября 1848 г.: «Покуда я читаю и перечитываю ваши письма...» Речь в обоих гоголевских посланиях шла, по-видимому, о письмах к нему о. Матфея по поводу «Выбранных мест из переписки с друзьями»: одно из них было получено Гоголем в начале января (н. ст.) 1848 г. в Неаполе ${ }^{75}$, другое - на Пасху 1848 г. в Константинополе ${ }^{76}$. (До этого, в 1847 г., Гоголь получил от о. Матфея еще два письма, непосредственно касающиеся «Выбранных мест...»; эти письма были вручены ему в Неаполе 8 мая (н. ст.) 1847 г. ${ }^{77}$ и в Остенде 24 сентября (н. ст.) 1847 г. $^{78}$ )

Позднее, в 1851 г., повода для подобных писем у о. Матфея, вероятно, не было; по крайней мере, сведения о таких письмах священника к Гоголю 1851 г. до нас не дошли.

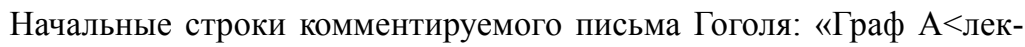
сандр $>$ П<етрович $>$ Толстой передал мне ваш поклон...», по-видимому, связаны с просьбой Гоголя к о. Матфею, высказанной в письме от 9 ноября 1848 г.: «...Скажите мне какое-нибудь слово... <..> Адресуйте $<\ldots><\ldots>$ Шевыреву, в Москве...» - Вместо письма о. Матфей передал Гоголю через графа Толстого только поклон. (Ср. также строки письма Гоголя к о. Матфею от 28 декабря 1848 г., свидетельствующие, что в этот период о. Матфей некоторое время не писал Гоголю: «Не знаю, как благодарить вас, добрейший Матвей Александрович, за ваш поклон мне в письме к графу Александру Петровичу...») Перечисленные факты позволяют отнести письмо Гоголя к протоиерею Матфею Константиновскому (с упоминанием о пребывании у него во Ржеве графа Толстого) к 28 ноября 1848 г.

\section{1}

К одному из двух посещений Гоголем святителя Филарета в конце 1848 г. $^{79}$ и в первой половине сентября 1851 г. ${ }^{80}$ относится недатирован-

${ }^{73}$ Виноградов И.А. Летопись жизни и творчества Н.В. Гоголя (1809-1852). Т. 6. C. 214

${ }^{74}$ Там же. C. 207.

75 Там же. Т. 5. C. $874,877$.

76 Там же. Т. 6. С. 53.

77 Там же. Т. 5. С. 686.

78 Там же. С. 834.

79 Там же. Т. 6. С. $227-228$.

${ }^{80}$ Там же. Т. 7. С. 135. 
ная записка Гоголя к С.П. Шевыреву, неточно отнесенная П.А. Кулишом $^{81}$, В.И. Шенроком ${ }^{82}$ и А.Н. Михайловой ${ }^{83}$ к концу 1851 г.

\section{2}

Еще одна ошибочная датировка гоголевского письма связана с неудачным визитом А-ра Мих. Марковича к Гоголю, в дом графа А.П. Толстого. После того как Марковича не приняли, Гоголь отправил ему записку с просьбой навестить его: «Вашу фамилию мне переврали. Я сижу больной и не могу видеть многих, но вас бы принял и с удовольствием побеседовал бы». В.И. Шенрок ${ }^{84}$ и вслед за ним А.Н. Михайлова $^{85}$ без объяснений отнесли записку к 1850 г. Между тем Маркович приехал в Москву в ноябре 1848 г. (см. выше), а уже в начале апреля 1849 г. покинул ее (см. письмо Гоголя к Марковичу от 1 июля 1849 г. в с. Сварково Черниговской губернии, а также предложенное ниже обоснование даты отправления прощального письма Гоголя к Марковичу от 3 апреля 1849 г.). Записка, вероятно, относится к январю 1849 г., поскольку в письме Гоголя к А.С. Данилевскому от января того же года (переданного тогда Марковичу для отправления на родину ${ }^{86}$ ) писатель тоже жалуется на здоровье: «Начинаю кое-как свыкаться с климатом, хотя не без простуд и насморков». Позднее, 25 февраля 1849 г., Гоголь сообщал Данилевскому: «Прости меня, я, кажется, огорчил тебя моим прежним письмом. <..> ...Может быть, болезнь, в которой я находился тогда (от которой еще не вполне освободился и теперь), ожесточила мои строки...»

\section{3}

Для короткой записки Гоголя к графу В.А. Соллогубу были предложены две даты: «На масленице 1849 или 1850 г.» (В.И. Шенрок) $)^{87}$; «Четверг, 10 февраля 1849 или 2 марта 1850. Москва» (А.Н. Михайлова) ${ }^{88}$. Текст записки гласит: «Завтра, т.е. в пятницу, около 5 часов, гр<аф> Толстой ждет вас к блинам. А с ним вместе и я». Основанием для уточнения датировки - 10 февраля 1849 г. — служит то, что Соллогуб был в Москве именно в феврале этого года ${ }^{89}$.

\footnotetext{
${ }^{81}<$ Гоголь Н.В. $>$ Соч. и письма Н.В. Гоголя. Изд. П.А. Кулиша. Т. 6. С. 550-551.

$82<$ Гоголь Н.В.> Письма Н.В. Гоголя. Ред. В.И. Шенрока. Т. 4. С. 419.

83 Гоголь Н.В. Полн. собр. соч.: В 14 т. Т. 14. С. 265, 438.

$84<$ Гоголь Н.В.> Письма Н.В. Гоголя. Ред. В.И. Шенрока. Т. 4. С. 315.

${ }^{85}$ См.: Гоголь Н.В. Полн. собр. соч.: В 14 т. Т. 14. С. 165, 407.

86 Виноградов И.А. Летопись жизни и творчества Н.В. Гоголя (1809-1852). Т. 6. C. $241-242,246$.

$87<$ Гоголь Н.В.> Письма Н.В. Гоголя. Ред. В.И. Шенрока. Т. 4. С. 235.

${ }^{88}$ Гоголь Н.В. Полн. собр. соч.: В 14 т. Т. 14. С. 172, 408.

89 Виноградов И.А. Летопись жизни и творчества Н.В. Гоголя (1809-1852). Т. 6. C. $248-249,267$.
} 


\section{4}

Апрелем 1849 или 1850 г. А.Н. Михайловой датировано пасхальное поздравление Гоголя, адресованное А-ру Мих. Марковичу ${ }^{90}$. Однако послание не может быть отнесено к 1850 г., поскольку, как уже отмечалось, в этом году Марковича в Москве не было. По-видимому, письмо относится ко дню Пасхи 3 апреля 1849 г. (в этот день Гоголь отправил еще несколько пасхальных поздравлений: к матери и сестрам, к В.А. Жуковскому, к П.А. Плетневу) и связано с близким отъездом Марковича из Москвы на родину. В конце записки Гоголь замечает: «Впрочем, надеюсь если не сегодня, так завтра с вами повидаться».

\section{5}

Весной 1850 г. датировано В.И. Шенроком ${ }^{91}$ (и вслед за ним А.Н. Михайловой ${ }^{92}$ ) объяснительное письмо Гоголя к графине Анне М. Виельгорской в Павлино по поводу его визита туда же 17 сентября 1848 г. Однако письмо определенно относится к весне 1849 г., т.е. написано в непродолжительное время после посещения Павлино (а не полтора года спустя).

Дата ответного письма Виельгорской неизвестна (письмо до нас не дошло), но сохранившийся ответ Гоголя имеет точное приурочение - он помечен 3 июня 1849 г. С учетом обычного времени обращения тогда писем между Москвой и Петербургом (и Павлино) это в целом позволяет предположительно датировать первое («объяснительное») письмо Гоголя к Виельгорской 24 мая 1849 г.: именно в этот день Гоголь написал в Павлино еще одно письмо - к сестре Анны Михайловны Виельгорской, графине С.М. Соллогуб (в тот же день он написал в Петербург и письмо к П.А. Плетневу). Содержание письма к Соллогуб определенно перекликается с содержанием послания к Виельгорской: «Скажу вам, что не один раз в это время я молил заочно и мысленно Анну Миха $<$ й>ловну и вас молиться за меня крепко и крепко. $<\ldots>$ Одна небольшая весточка о том, что вы делаете теперь все в Павлине, одно описание дня вашего принесет мне много, много утешенья. Если бы вы знали, как вы все до единого стали теперь ближе моему сердцу, чем когда-либо прежде...» ${ }^{93}$

\section{6}

В зависимости от датировки письма Н.Н. Шереметевой к Гоголю находится его ответная записка $1849 r{ }^{94}$ следующего содержания: «Когда

${ }^{90}$ См.: Гоголь Н.В. Полн. собр. соч.: В 14 т. Т. 14. С. 176, 410.

$91<$ Гоголь Н.В.> Письма Н.В. Гоголя. Ред. В.И. Шенрока. Т. 4. С. 309-311.

92 См.: Гоголь Н.В. Полн. собр. соч.: В 14 т. Т. 14. С. 187, 413-414.

93 Подробнее о цели визита Гоголя в Павлино 17 сентября 1848 г. см.: Виноградов И.А. Летопись жизни и творчества Н.В. Гоголя (1809-1852). Т. 6. С. 152-160.

94 Гоголь Н.В. Полн. собр. соч.: В 14 т. Т. 14. С. 159, 405. 
вам угодно. Мне всегда приятно на вас взглянуть. Берегите только свое здоровье и не выезжайте, когда погода дурна». Вероятно, ответ Гоголя вызван сообщением Шереметевой о намерении с ним встретиться: «Приезд внука ${ }^{95}$ меня тут задержал. 8<-го> поеду в деревню, и не хочется оставить Москву, не взглянувши еще раз на вас». Записка Шереметевой помечена: «Воскресенье. Ноября 6». Хотя год отправления в послании не указан, однако на 6 ноября воскресный день приходился в 1849 г. Кроме того, как явствует из письма Шереметевой от 20 ноября 1848 г. (в ответ на письмо Гоголя от 26 октября 1848 г.), в ноябре 1848 г. ее в Москве не было. По-видимому, записку Гоголя следует приурочить к тому же числу - 6 ноября 1849 г.

\section{7}

Ко времени отъезда Шереметевой из Москвы, 8 ноября 1849 г. (см. выше), вероятно, относится еще одна записка к ней Гоголя, приблизительно датированная А.Н. Михайловой этим годом («1849. Москва») ${ }^{96}$ : «Очень сожалею, что не видал вас. Когда вы были у меня, тогда я был у обедни, не думая, что вы приедете в такое время. <..> Прощайте. Не забывайте меня по-прежнему ни дружескими письмами, ни молитвами» ${ }^{97}$. Однако в то же время можно предположить, что это послание относится к концу марта - апрелю того же года, времени еще одного пребывания Шереметевой в Москве в 1849 г. $^{98}$

\section{8}

Недатированная записка Гоголя к С.П. Шевыреву, в которой он сообщает, что давно не видел приятеля и «в это время сильно расхворался» («да и теперь еще не совсем оправился»), отнесена П.А. Кулишом ${ }^{99}$, а вслед за ним В.И. Шенроком ${ }^{100}$ (а затем и А.Н. Михайловой ${ }^{101}$ ) к концу 1851 г. Однако более вероятно, что послание было написано в период болезни Гоголя после 3 февраля — не позднее 13 февраля 1850 г. ${ }^{102}$

95 Е.И. Якушкин. См. также письмо Шереметевой к Гоголю из с. Покровское Рузского уезда от 12 сентября 1848 г. (Виноградов И.А. Летопись жизни и творчества Н.В. Гоголя (1809-1852). Т. 6. С. 148-149).

96 Гоголь Н.В. Полн. собр. соч.: В 14 т. Т. 14. С. 159, 405.

97 См.: Виноградов И.А. Летопись жизни и творчества Н.В. Гоголя (1809-1852).

T. 6. C. 395 .

98 Там же. С. $262,301$.

$99<$ Гоголь Н.В.> Соч. и письма Н.В. Гоголя. Изд. П.А. Кулиша. Т. 6. С. 550.

$100<$ Гоголь Н.В.> Письма Н.В. Гоголя. Ред. В.И. Шенрока. Т. 4. С. 417.

101 Гоголь Н.В. Полн. собр. соч.: В 14 т. Т. 14. С. 265, 438.

102 Виноградов И.А. Летопись жизни и творчества Н.В. Гоголя (1809-1852). Т. 6. C. $436-437$. 


\section{9}

Довольно приблизительно и опять-таки ошибочно датирована связанная с предыдущей записка Гоголя к С.П. Шевыреву, где он вновь упоминает о своей болезни: «Как ни хочется тебя видеть, но лучше поберечься. По вечерам особенно мне нехорошо выезжать. Раз было попробовал, но простудился опять. Теперь хоть и лучше, но всё еще не пришел в обыкновенное состояние». Записка помечена: «Четверг». А.Н. Михайлова сопроводила записку указанием: «Зима 1848/49 или $1851 / 52$. Москва» ${ }^{103}$.

Однако ни к зиме 1848/49, ни к зиме 1851/52 г. записка не относится. Судя по всему, она представляет собой ответ Гоголя на приглашение Шевырева на вечер 24 февраля 1850 г., на котором А.Н. Островский читал свою комедию «Банкрут» («Свои люди - сочтемся») ${ }^{104}$. (Ранее, 3 декабря 1849 г., Гоголь уже слушал эту комедию на вечере у М.П. Погодина ${ }^{105}$.) Гоголь извещает Шевырева, что «простудился опять», вероятно, подразумевая под этим свою болезнь в первой половине февраля 1850 г., о которой он тогда же писал Шевыреву (см. выше). Сообщает также, что теперь ему «лучше» («но всё еще не пришел в обыкновенное состояние»). Об этом же на следующий день, в пятницу 24 февраля 1850 г., С.Т. Аксаков сообщал сыну Ивану: «Гоголь $<\ldots>$ опять занемог.. < ..> вчера ему стало лучше» ${ }^{106}$. Следовательно, записку следует датировать четвергом 23 февраля 1850 г.

\section{0}

К весне 1849 г. В.И. Шенрок ${ }^{107}$ и вслед за ним А.Н. Михайлова ${ }^{108}$ ошибочно отнесли письмо Гоголя к матери, начинающееся словами: «Я получил ваше большое и весьма обстоятельное письмо, почтеннейшая и добрейшая матушка». П.А. Кулишом это письмо было, однако, датировано 1850 г. ${ }^{109}$ Датировка Кулиша более соответствует содержанию письма. Показательно, что в другом письме к родным того времени, от средины апреля 1850 г. (см. ниже), Гоголь благодарит сестру Анну за исполнение просьбы о насаждении садовых деревьев, изложенную

\footnotetext{
${ }_{103}^{103}$ Гоголь Н.В. Полн. собр. соч.: В 14 т. Т. 14. С. 272.

104 Виноградов И.А. Летопись жизни и творчества Н.В. Гоголя (1809-1852). Т. 6. C. 450.

105 Там же. С. 403-408. C. 450 .

106 Виноградов И.А. Летопись жизни и творчества Н.В. Гоголя (1809-1852). Т. 6.

$107>$ Гоголь Н.В.> Письма Н.В. Гоголя. Ред. В.И. Шенрока. Т. 4. С. 253.

108 Гоголь Н.В. Полн. собр. соч.: В 14 т. Т. 14. С. 129, 395.

$109<$ Гоголь Н.В.> Соч. и письма Н.В. Гоголя. Изд. П.А. Кулиша. Т. 6. С. 521.
} 
в настоящем письме. Содержащееся тут же обещание прислать сестре «семян огородных овощей» Гоголь тоже выполнил во второй половине апреля 1850 г. (см. его письмо к сестрам Анне и Ольге от средины апреля и письмо к матери и сестрам около 23 апреля 1850 г.). О работах сестры Анны в саду «вместе с племянником» Гоголь, в свою очередь, упоминает в тех же апрельских письмах 1850 г. (О привлечении племянника Н.П. Трушковского к садовым занятиям Гоголь впервые упомянул в письме к матери от 4 июля 1849 г., что тоже не позволяет отнести комментируемое письмо к весне 1849 г.) Письмо следует датировать первой половиной марта 1850 г.

\section{1}

Так же ошибочно отнесено к весне 1849 г. ${ }^{110}$ короткое послание Гоголя к матери, в котором он извещает, что «семена» для огорода вскоре доставит ей И.О. Петрашевский. Послание это находится в тесной связи с предшествующим письмом, где сообщалось о предполагаемой присылке «семян огородных овощей». Его следует датировать срединой марта 1850 г.

\section{2}

Общей ошибкой П.А. Кулиша ${ }^{111}$, В.И. Шенрока ${ }^{112}$, А.Н. Михайловой ${ }^{113}$ является датировка письма Гоголя к матери и сестрам Анне и Ольге, начинающегося пасхальным приветствием: «Христос Воскресе! Наконец получил от вас письма». Письмо было ошибочно отнесено исследователями к 1849 г. Имеются основания датировать его годом позже.

В письме говорится о тяжелом материальном положении Васильевки, о котором Гоголь только что узнал из полученных от родных писем. По-видимому, именно это известие вскоре, во второй половине апреля 1850 г. (между 23 и 27 числами), побудило Гоголя обратиться к П.А. Плетневу с просьбой прислать из Петербурга оставшиеся у того деньги: «Дела матери моей и сестер от неурожаев и голодов пришли в такое расстройство, $<\ldots>$ что я принужден собрать всё, какое у меня еще осталось имущество, и спешить сам к ним на помощь. Потрудись взять из ломбарда последний оставш<ийся> мой билет на 1168 руб<лей> серебром...»

\footnotetext{
${ }^{110}$ Гоголь Н.В. Полн. собр. соч.: В 14 т. Т. 14. С. 131, 395.

$111<$ Гоголь Н.В.> Соч. и письма Н.В. Гоголя. Изд. П.А. Кулиша. Т. 6. С. 483.

$112<$ Гоголь Н.В.> Письма Н.В. Гоголя. Ред. В.И. Шенрока. Т. 4. С. 246.

113 Гоголь Н.В. Полн. собр. соч.: В 14 т. Т. 14. С. 113, 390.
} 
Кроме того, в письме в Васильевку Гоголь вновь упоминает о работах в саду старшей сестры Анны и племянника Коли (см. выше обоснование датировки письма Гоголя к матери от первой половины марта 1850 г.).

Послание следует датировать срединой апреля 1850 г.

\section{3}

К марту-апрелю 1850 г. А.Н. Михайлова ${ }^{114}$ отнесла письмо Гоголя к сестре Елисавете, в котором он просит и ее (как ранее сестру Анну) принять участие в работах на огороде: «Хоть ты и пишешь, милая сестра Елисавета, что у тебя, куча занятий, но все-таки будет недурно, если ты сверх этой кучи возьмешь на себя хоть одну грядочку...» Кроме того, Гоголь упоминает в письме о неудаче «насчет помещенья» в сиротский институт воспитанницы Гоголей Эмилии Ващенко ${ }^{115}$, об устройстве которой в это петербургское заведение он хлопотал в течение года, с февраля 1849 по февраль 1850 г. ${ }^{116}$ По-видимому, письмо к сестре Елисавете было отправлено одновременно с письмом к матери и сестрам Анне и Ольге в средине апреля 1850 г.

\section{4}

Особого внимания заслуживает новая датировка письма Гоголя из Одессы в Москву к цензору В.Н. Лешкову по поводу переиздания своих сочинений в четырех томах. А.Н. Михайлова ошибочно полагала, что послание было написано в Москве летом 1851 г. ${ }^{117}$ Этому предположению определенно противоречат данные о службе Лешкова. Профессор Московского университета Василий Николаевич Лешков (1810-1881) исполнял должность цензора Московского цензурного комитета с 21 января 1847 г. до 17 ноября 1850 г. ${ }^{118}$ (в частности, был цензором «Москвитянина»). 28 ноября 1850 г. С.П. Шевырев, отвечая на предложение Гоголя в письме от 7 ноября 1850 г. отдать экземпляр собрания сочинений 1842 г. Лешкову, сообщал: «С будущего года новые цензоры. Лешков из цензоров выходит, потому что, по новому уставу, профессор цензором

114 Там же. С. $175,410$. См. также: <Гоголь Н.B.> Письма Гоголя. Примеч. В. Гиппиуса, Л. Пономарева, С. Дурылина и Г. Залкинда // Н.В. Гоголь. Материалы и исследования. Под ред. В.В. Гиппиуса. М.; Л., 1936. Т. 1. С. 119 (коммент. В.В. Гиппиуса).

C. 230 .

Виноградов И.А. Летопись жизни и творчества Н.В. Гоголя (1809-1852). Т. 5.

116 Там же. Т. 6. С. 246, 377, 401, 438.

117 Гоголь Н.В. Полн. собр. соч.: В 14 т. Т. 14. С. 244, 430.

118 Гринченко Н.А., Патрушева Н.Г. Цензоры Москвы, 1804-1917 (аннотированный список) // Новое литературное обозрение. 2000. № 44. С. 425. 
быть не может». Ответ на это письмо Шевырева Гоголь отправил 15 декабря 1850 г. Извещенный о том, что Лешков «из цензоров выходит», он в то время уже не стал бы обращаться к этому цензору. Поэтому его письмо к Лешкову следует датировать «одесским» периодом после 7 ноября до начала декабря 1850 г.

\section{5}

Второй половиной 1851 г. было приблизительно датировано А.Н. Михайловой ${ }^{119}$ письмо Гоголя в Рим к А.А. Иванову (ответ на письмо художника от 8/20 мая 1851 г.). Уточнить датировку позволяет упоминание в начале письма о Н.П. Боткине, с которым Гоголь передает письмо: «Николай Петрович Ботки $<_{\mathrm{H}}>$ передаст вам мой поцелуй, многолюбимый мною Александр Андре $<$ вв>ич». Боткин отправлялся из Москвы в Рим через Петербург, где 18 августа 1851 г. соответствующее письмо к Иванову в Рим передал ему также Ф.И. Иордан ${ }^{120}$. На этом основании гоголевское письмо к Иванову следует отнести к концу июля началу августа 1851 г.

\section{6}

Приблизительно к концу 1851 г. А.Н. Михайлова ${ }^{121}$ отнесла, вслед за П.А. Кулишом ${ }^{122}$ и В.И. Шенроком ${ }^{123}$, следующую недатированную записку Гоголя к С.Т. Аксакову: «Поздравляю вас от всей души, что же до меня, то хотя и не могу похвалить $<$ ся $>$ тем же, но если Бог будет милостив и пошлет несколько деньков, подобных тем, какие иногда удаются, то, может быть, и я как-нибудь управлюсь».

Свидетельства Аксаковых позволяют точно датировать записку Гоголя. По-видимому, послание написано 7 ноября 1851 г. В этот день Гоголь побывал на «новоселье» О.Сем., И.С., В.С. и Н.С. Аксаковых, снявших флигель в доме П.А. Серединской на Арбате, в Николо-Песковском переулке. На следующий день, 8 ноября 1851 г., В.С. Аксакова сообщала М.Г. Карташевской: «Вчера перебывали у нас все родные и знакомые. Кошелева и Гоголь сидели вечер... <..> Отесенька очень прилежно занимается своими записками ${ }^{124}$ и подстрекает Гоголя» ${ }^{125}$.

119 Гоголь Н.В. Полн. собр. соч.: В 14 т. Т. 14. С. 263, 437.

${ }^{120}$ См.: Виноградов И.А. Летопись жизни и творчества Н.В. Гоголя (1809-1852).

T. 7. C. 121.

${ }_{121}$ Гоголь Н.В. Полн. собр. соч.: В 14 т. Т. 14. С. 264, 438.

$122<$ Гоголь Н.В.> Соч. и письма Н.В. Гоголя. Изд. П.А. Кулиша. Т. 6. С. 550.

$123<$ Гоголь Н.В.> Письма Н.В. Гоголя. Ред. В.И. Шенрока. Т. 4. С. 417.

124 Имеются в виду «Записки ружейного охотника Оренбургской губернии».

125 Виноградов И.А. Летопись жизни и творчества Н.В. Гоголя (1809-1852). Т. 7. C. 187 . 
Поскольку отец Аксаковой, Сергей Тимофеевич, находился в то время в подмосковном имении Радонежье (Абрамцево), то, очевидно, Вера Сергеевна имела в виду одно из тогдашних несохранившихся писем ее отца к Гоголю. На одно из таких писем С.Т. Аксакова Гоголь отвечал около 17 октября 1851 г. Однако в письме от 8 ноября 1851 г. В.С. Аксакова, по-видимому, имеет в виду другое письмо ее отца, на которое и откликнулся тогда Гоголь. (Вскоре, 9 ноября, О.Сем. и В.С. Аксаковы уехали из Москвы в Радонежье и, вероятно, тогда же привезли С.Т. Аксакову ответную записку Гоголя.)

Племянник Гоголя Н.П. Трушковский, издатель посмертного собрания его сочинений, впервые опубликовавший в 1855 г. записку Гоголя ${ }^{126}$, полагал, что она написана «незадолго уже до кончины» ${ }^{127}$ писателя. Однако, поясняя письмо, Трушковский, который познакомился с В.С. Аксаковой в декабре 1854 г. ${ }^{128}$ (а также общался с нею в марте 1855 г. ${ }^{129}$ ), почти повторяет выражения приведенного выше ее письма к Карташевской от 8 ноября 1851 г.: «Для объяснения этой записки $<$ Гоголя>, надобно сказать, что Гоголь и С.Т. Аксаков сделали между собою условие, чтобы Гоголь приготовил осенью 1851 года к печати 2-й том "Мертвых душ", a $\Gamma<\mathrm{H}>\mathrm{A}<$ ксаков $>-$ свои “Записки Ружейного Охотника”, и чтобы зимою вместе начать их печатание. $\Gamma<\mathrm{H}>\mathrm{A}<$ ксаков $>$ кончил свою работу $^{130}$ и, желая подстрекнуть Гоголя, уведомил его об этом немедленно и получил в ответ вышеприведенную записку» ${ }^{131}$. (Ср. выше в письме Аксаковой: «Отесенька очень прилежно занимается своими записками и подстрекает Гоголя».)

Предложенная датировка записки Гоголя подтверждается также свидетельствами С.Т. Аксакова. Хотя на подлиннике письма имеется его помета: «Конец 1851», - однако в своих мемуарах Аксаков относил письмо Гоголя к осени 1851 г. 12 июня 1852 г. он писал матери Гоголя

${ }^{126}$ Трушковский Н. От издателя // <Гоголь Н.В.> Сочинения Николая Васильевича Гоголя, найденные после его смерти / Похождения Чичикова, или Мертвые души. Поэма Н.В. Гоголя. Том второй (5 глав). М., 1855. С. VI.

127 Там же. C. V-VI.

128 Виноградов И.А. Летопись жизни и творчества Н.В. Гоголя (1809-1852). Т. 6. C. 367.

${ }^{129}$ См.: Куліш П.А. Листи до М.Д. Білозерского. Упорядковання, вступна стаття й коментарі О. Федорука. Львів; Нью-Йорк, 1997. С. 201; Виноградов И.А. Первый биограф Гоголя // Кулиш П.А. Записки о жизни Николая Васильевича Гоголя, составленные из воспоминаний его друзей и знакомых и из его собственных писем / Изд. подгот. И.А. Виноградов. М., 2003. С. 41.

${ }^{130}$ Несколько месяцев спустя, 9 января 1852 г., Аксаков даже сообщал Гоголю, что отправил первую половину «Записок ружейного охотника...» в Москву, «чтобы процензуровать и печатать», обещая прислать через неделю «остальную половину» (см.: Виноградов И.А. Летопись жизни и творчества Н.В. Гоголя (1809-1852). Т. 7. C. 227).

Трушковский Н. От издателя. С. VI. 
в Васильевку: «Гоголь хотел непременно еще осенью побывать у нас ${ }^{132}$; [но уже не собрался] но не вдруг собрался, а потом захватила осенняя погода. Между тем бодрость к нему воротилась и он писал ко мне, что работает успешно (имеется в виду письмо Гоголя к С.Т. Аксакову от октября 1851 г. - И.В.). В одном письме (подразумевается комментируемое письмо. - И.В.) даже говорит, что если б Бог дал ему еще таких денька два-три, то второй том был бы готов. Мы переписывались довольно часто. Я подстрекал его тем, что мои Записки ружейного охотника скоро будут готовы: Гоголь отвечал весело, что от меня не отстанет (имеется в виду письмо Гоголя к С.Т. Аксакову от 20 сентября 1851 г. - И.В.). Но это продолжалось недолго» ${ }^{133}$.

В 1854 г. С.Т. Аксаков в адресованном П.А. Кулишу «Продолжении кратких сведений и выписок из писем для биографии Гоголя» повторял: «В продолжение октября и ноября Гоголь, вероятно, чувствовал себя лучше и мог успешно работать, что доказывается несколькими его записками. В одной из них (от октября 1851 г. - И.В.), между прочим, он писал: “Слава Богу за все. Дело кое-как идет. Может быть, оно и лучше, если мы прочитаем друг другу зимой, а не теперь. Теперь время еще какого-то беспорядка, как всегда бывает осенью, когда человек возится и выбирает место, как усесться, а еще не уселся..." Следующие слова из другой записки показывают, что Гоголь был доволен своей работой: “...Если Бог будет милостив и пошлет несколько деньков, подобных тем, какие иногда удаются, то, может быть, я как-нибудь управлюсь”» ${ }^{134}$.

\section{7}

К концу октября - началу ноября 1850 г., т.е. ко времени проживания Гоголя в Одессе, ошибочно отнесено В.В. Гиппиусом ${ }^{135}$ (а затем А.Н. Михайловой $\left.{ }^{136}\right)$ гоголевское письмо к сестре Анне, в котором он пеняет ей на непослушание: «Я не сержусь на тебя и даже не удивляюсь твоему отъезду, потому что ты еще ни одного разу меня не послушалась».

Вопреки предположениям исследователей письмо следует датировать целым годом позднее, а именно 8 ноября 1851 г., когда Гоголь отправил из Москвы в Кагорлык (Киевской губернии) письмо, адресо-

${ }_{132}^{132}$ В Радонежье (Абрамцево).

133 Аксаков С.T. Выписка слово в слово из моих кратких заметок $<_{0}$ Гоголе >. $<$ Письмо к М.И. Гоголь-Яновской>. 12 июня 1852 года // Виноградов И.А. Гоголь в воспоминаниях, дневниках, переписке современников. Т. 2. С. 626.

134 Аксаков C.T. Продолжение кратких сведений и выписок из писем для биографии Гоголя. $<1845-1852$ гг. $><$ Письмо к П.А. Кулишу $><$ Июль-октябрь 1854> // Виноградов И.А. Гоголь в воспоминаниях, дневниках, переписке современников. T. 2. C. 654 .

$135<$ Гоголь Н.В.> Письма Гоголя. С. 121.

136 Гоголь Н.В. Полн. собр. соч.: В 14 т. Т. 14. С. 207, 420-421. 
ванное только что вышедшей тогда замуж сестре Елисавете и ее мужу В.И. Быкову. В отправленном одновременно с этим посланием письме к сестре Анне Гоголь выговаривает ей на неисполнение его пожелания, которое он высказал за месяц перед тем, в письме от 3 октября 1851 г., остаться с матерью в Васильевке (а не ехать с сестрой в Кагорлык): «А ты, милая сестра моя Анна, не поскучай своим пребываньем с матушкой в деревне» (письмо от 3 октября). Младшая сестра Гоголя Ольга, вспоминая об отъезде из Васильевки сестры Елисаветы с мужем, также замечала: «...Они уехали, и Аннет с ними, несмотря на то, что брат писал матери, чтобы никто из нас не ездил к ним; пусть они вдвоем хоть год поживут. Но Лиза просила Аннет ехать с ними, потому что еще не успела к мужу привыкнуть» ${ }^{137}$. (В конце декабря 1851 г. в Кагорлык к молодым отправилась и сама М.И. Гоголь с дочерью Ольгой ${ }^{138}$.)

\section{8}

Сентябрем 1851 г. традиционно датируется рекомендательная записка к М.П. Погодину, написанная Гоголем для П.В. Анненкова ${ }^{139}$. В то время Анненков приступил к собиранию материалов к пушкинской биографии ${ }^{140}$ и искал встречи с Погодиным. Автограф письма не датирован $^{141}$. Н.П. Барсуков, впервые опубликовавший эту записку в 1897 г., отнес ее предположительно (без всяких объяснений) к сентябрю 1851 г.: «В сентябре 1851 года Гоголь писал Погодину...» ${ }^{142}$ Между тем еще в 1855 г., т. е. за сорок лет до Барсукова, сам Анненков в «Материалах для биографии А.С. Пушкина» сообщал, что его встреча с Гоголем, во время которой они разговаривали о Пушкине, произошла около конца ноября 1851 г.: «...Таково было обаяние личности поэта нашего <А.С. Пушкина >, что когда за три месяца до смерти Гоголя (т.е. в конце ноября 1851 г. - И.В.) составитель этих материалов напомнил ему о Пушкине, то мог видеть, как переменилась, просветлела и оживилась его физиономия...» ${ }^{143}$ На этом основании записку Гоголя следует датировать концом ноября 1851 г.

137 Виноградов И.А. Летопись жизни и творчества Н.В. Гоголя (1809-1852). Т. 7. C. 155

138 Там же. С. 211, 222, 260.

139 Гоголь Н.В. Полн. собр. соч.: В 14 т. Т. 14. С. 253.

140 «Материалы для биографии А.С. Пушкина» П.В. Анненкова составили первый том подготовленного им издания сочинений поэта (СПб., 1855-1857. Т. 1-7).

${ }^{141}$ См.: РГАЛИ. Ф. 2819. Оп. 1. Ед. хр. 122. 2 л.

142 Барсуков Н.П. Жизнь и труды М.П. Погодина. В 22 кн. СПб., 1897. Кн. 11. C. 311 ,

143 Анненков П.В. Материалы для биографии А.С. Пушкина // Виноградов И.А. Гоголь в воспоминаниях, дневниках, переписке современников. Т. 3. С. 417. 
Временем «около 10 февраля» 1852 г. неточно датировано В.В. Гиппиусом ${ }^{144}$ и А.Н. Михайловой ${ }^{145}$ ответное письмо Гоголя к матери, вероятно, адресованное в Кагорлык, куда Мария Ивановна на время приезжала к вышедшей замуж дочери Елисавете (см. выше обоснование датировки письма Гоголя к сестре Анне 8 ноября 1851 г.). На то, что послание следует датировать 1852 г., указывает упоминание здесь о болезни матери (ее «воспалительностях в крови»), о предполагаемом «весеннем леченье травами», а также пожелание Гоголя матери «посоветоваться с хорошим доктором». По-видимому, не рассчитывая на то, что в Кагорлыке будут получены его письма к матери и к сестре Ольге, отправленные в Васильевку 22 декабря 1851 г. (письма эти действительно были получены М.И. Гоголь и ее младшей дочерью лишь по возвращении их вместе со старшей дочерью Анной из Кагорлыка $\left.{ }^{146}\right)$, Гоголь в комментируемом письме повторяет пожелания в письме к младшей сестре от 22 декабря: «Я полагаю, что матушке полезно было весеннее лечение для перечистки крови и уменьшенья ее воспалительности. <... Посоветуйся и расспроси у какого-нибудь умного доктора» (письмо от 22 декабря). Далее, в письме от 2 февраля 1852 г. Гоголь писал, что давно уже не получал известий из дома. Следовательно, письмо, которое является ответом на послание матери, не могло быть написано ранее 2 февраля. С другой стороны, письмо, по-видимому, не могло быть отправлено и позднее 11 февраля 1852 г. (начало Великого Поста в 1852 г.: Гоголь упоминает о нем в письме). Датировать письмо следует, вероятно, 3-4 февраля 1852 г. Начиная с 5-го числа, когда Гоголь проводил о. Матфея Константиновского, гостившего в доме графа А.П. Толстого, настроение его меняется - он уже не думает о «трудах» и «обычных делах», упоминаемых в письме к матери ${ }^{147}$.

\section{0}

Широким временным промежутком - с конца 1848 до начала 1852 г. - датирована А.Н. Михайловой ${ }^{148}$ следующая записка Гоголя к С.Т. Аксакову: «Обнимаю вас заочно и очень жалею, что не могу об-

\footnotetext{
$144<$ Гоголь Н.B. $>$ Письма Гоголя. С. 123-124.

145 Гоголь Н.В. Полн. собр. соч.: В 14 т. Т. 14. С. 271, 442.

146 Свидетельство О.В. Гоголь-Головни (см.: Виноградов И.А. Летопись жизни и творчества Н.В. Гоголя (1809-1852). Т. 7. С. 222).

${ }_{147}$ Виноградов И.А. Летопись жизни и творчества Н.В. Гоголя (1809-1852). Т. 7. C. $269-272$.

${ }^{148}$ Гоголь Н.В. Полн. собр. соч.: В 14 т. Т. 14. С. 272, 442.
} 
нять лично. Напишите о себе иногда строчку». Можно предположить, что записка представляет собой прямой ответ Гоголя на столь же краткое письмо Аксакова из Радонежья (Абрамцево) от 11 февраля 1852 г.: «Зачем же вы хвораете, друг мой? Я третий день опять болен и начал лечиться земляничным корнем. Константин (старший сын Аксакова. - И.В.) уехал с тем, чтоб побывать у вас. Крепко вас обнимаю». «Заочные» объятия друзей стали последними.

Кроме перечисленных уточнений дополнительно отметим ошибочное указание места отправления одного из писем Гоголя. Имеется в виду письмо к К.М. Базили, генеральному консулу в Сирии и Палестине, сопровожденное писателем пометой: «5 июня 1849 г.». А.Н. Михайлова добавила к этому авторскому указанию неверное уточнение: «Москва» ${ }^{149}$. На самом деле письмо было написано не в Москве, а во время пребывания Гоголя в тот день вместе с М.П. Погодиным в Остафьево, подмосковном имении князя П.А. Вяземского. Тогда же - и там же оно, видимо, и было передано Вяземскому, отправлявшемуся в то время в Константинополь ${ }^{150}$.

Таким образом, соответствующее хронологическое приурочение получили следующие, по годам, пятьдесят писем Гоголя: по одному письму 1822, 1836, 1840-1841, 1842, 1843 и (одно) 1848 или 1851 гг., по два письма - 1838, 1841, 1844, 1845, 1848 и 1852 гг., три письма - 1837 г., четыре - 1851, пять - 1839, по шесть писем - 1849 и 1850 гг, семь писем -1840 г.

149 Там же. С. 133.

150 Виноградов И.А. Летопись жизни и творчества Н.В. Гоголя (1809-1852). Т. 6. C. $310-311$. 


\section{Литература}

Виноградов И.А. Гоголь в воспоминаниях, дневниках, переписке современников. Полный систематический свод документальных свидетельств: В 3 т. М.: ИМЛИ PAH, 2011-2013. 904, 1031, 1168 с.

Виноградов И.А. Гоголь на пути в Рим в 1840 г. Из истории общения писателя с современниками // Гоголезнавчі студії. Вып. 4 (21). Ніжин, 2014. С. 12-18.

Виноградов И.А. Летопись жизни и творчества Н.В. Гоголя (1809-1852). С родословной летописью (1405-1808): В 7 т. М.: ИМЛИ РАН, 2017-2018. 736, 672, 672, 704, 928, 656, $640 \mathrm{c}$.

Виноградов И.А. Неузнанное произведение Гоголя // Духовная традиция в русской литературе: Сб. научных статей / Науч. ред., сост. Г.В. Мосалевой. Ижевск: Изд-во Удмуртского ун-та, 2013. С. 236-248.

Виноградов И.А. Первый биограф Гоголя // Кулиш П.А. Записки о жизни Николая Васильевича Гоголя, составленные из воспоминаний его друзей и знакомых и из его собственных писем / Изд. подгот. И.А. Виноградов. М.: ИМЛИ РАН, 2003. C. $3-81$.

Гоголь Н.В. Полн. собр. соч. и писем: В 17 т. (15 кн.) / Сост., подгот. текстов и коммент. И.А. Виноградова, В.А. Воропаева. М.; Киев: Изд-во Московской Патриархии, 2009-2010. 664, 688, 680, 744, 816, 720, 968, 392, 488, 704, 592, 608, 624, $816,936 \mathrm{c}$.

Гринченко Н.А., Патрушева Н.Г. Цензоры Москвы, 1804-1917 (аннотированный список) // Новое литературное обозрение. 2000. № 44. С. 409-433.

Дневник Софьи Борисовны Шевыревой. Подгот. к публ. и коммент. А.А. Горохова, пер. с фр. М.О. Ноздренко // Историческое образование. 2014. № 4. С. 177-191.

Куліш П.А. Листи до М.Д. Білозерского. Упорядковання, вступна стаття й коментарі О. Федорука. Львів; Нью-Йорк, 1997. 224 с.

\section{References}

Dnevnik Sof'i Borisovny Shevyrevoi [Sophia Borisovna Shevyreva's diary], ed. and comment. by A.A. Gorokhov, transl. from French by M.O. Nozdrenko. Istoricheskoe obrazovanie, 2014, no. 4, pp. 177-191. (In Russ.)

Gogol' N.V. Poln. sobr. soch. i pisem: V $17 t$. (15 kn.) [Complete works and letters in 17 vols. (15 books)], comp., ed. and comment. by I.A. Vinogradov, V.A. Voropaev. Moscow, Kiev, Moscow Patriarchy Publ., 664, 688, 680, 744, 816, 720, 968, 392, 488, 704, 592, 608, 624, 816, 936 p. (In Russ.)

Grinchenko N.A., Patrusheva N.G. Tsenzory Moskvy, 1804-1917 (annotirovannyi spisok) [Moscow censors, 1804-1917 (annotated list)]. Novoe literaturnoe obozrenie, 2000, no. 44, pp. 409-433. (In Russ.)

Kulish P.A. Lysty do M.D. Bilozerskogo [Letters to M.D. Bilozersky], comp., intro. and comment. by O. Fedoruk. Lviv, New York, 1997. 224 p. (In Russ., in Ukr.)

Vinogradov I.A. Gogol' na puti v Rim v 1840 g. Iz istorii obshcheniia pisatelia s sovremennikami [Gogol on his way to Rome in 1840. From the history of writer's 
interaction with his contemporaries]. Gogoleznavchi studï [Studies on Gogol], iss. 4 (21). Nizhyn, 2014, pp. 12-18. (In Russ.)

Vinogradov I.A. Gogol'v vospominaniiakh, dnevnikakh, perepiske sovremennikov. Polnyi sistematicheskii svod dokumental'nykh svidetel'stv: $V \quad 3 t$. [Gogol in his contemporaries' memoirs, diaries and correspondence. Complete systematic set of documentary evidence, in 3 vols.]. Moscow, Institute of World Literature Publ., 20112013. 904, 1031, 1168 p. (In Russ.)

Vinogradov I.A. Letopis' zhizni i tvorchestva N.V. Gogolia (1809-1852). S rodoslovnoi letopis'iu (1405-1808): V $7 t$. [Chronicle of life and work of N.V. Gogol (1809-1852). With the genealogic chronicle (1405-1808), in 7 vols.]. Moscow, Institute of World Literature Publ., 2017-2018. 736, 672, 672, 704, 928, 656, 640 p. (In Russ.)

Vinogradov I.A. Neuznannoe proizvedenie Gogolia [Unidentified work by Gogol]. Dukhovnaia traditsiia $v$ russkoi literature: Sb. nauchnykh statei [The spiritual tradition in Russian literature: A collection of scholarly articles], ed., comp. by G.V. Mosaleva. Izhevsk: Udmurt University Publ., 2013, pp. 236-248. (In Russ.)

Vinogradov I.A. Pervyi biograf Gogolia [The first biographer of Gogol]. Kulish P.A. Zapiski o zhizni Nikolaia Vasil'evicha Gogolia, sostavlennye iz vospominanii ego druzei $i$ znakomykh i iz ego sobstvennykh pisem [Notes on the life of Nikolai Vasilyevich Gogol compiled from memoirs of his friends and acquaintances and from his letters], comp. by I.A. Vinogradov. Moscow, Institute of World Literature Publ., 2003, pp. 3-81. (In Russ.)

\title{
New dating of N.V. Gogol's fifty letters
}

\section{(C) 2018, Igor Vinogradov}

\begin{abstract}
The article is devoted to the objective reconstruction of Gogol's correspondence and biography. Dating of Gogol's fifty letters to different correspondents are corrected. Exceptionally significant cases of erroneous dating, from some months to several years, are presented. The article does not consider those cases when the dating differs on one or two days, when Gogol sends a letter the next or the second day after it is written. Letters from all periods of Gogol's life and creative work: seven letters of 1840 , six of 1849 and 1850 , five of 1839 , four of 1851 , three of 1837 , two of $1838,1841,1844,1845,1848$ and 1852, one of $1822,1836,1840-1841$, 1842,1843 and one of 1848 or 1851 received a new dating corresponding to reality. Numerous historical and archival materials, biographical information, memoirs and epistolary sources etc. are used for argumentation.

Keywords: Gogol, biography, creative work, epistolary heritage, dating, correspondents

Information about the author: Igor Vinogradov, Doctor Hab. of Philology, Chief Researcher, Gorky Institute of World Literature of Russian Academy of Sciences, Moscow, Russia. E-mail: info@imli.ru
\end{abstract}

Citation: Vinogradov Igor. New dating of N.V. Gogol's fifty letters. Literary fact, 2018, no. 10 , pp. $393-427$ 